\title{
Metatranscriptome Analysis of Sympatric Bee Species Identifies Bee Virus Variants and a New Virus, Andrena-Associated Bee Virus-1
}

\author{
Katie F. Daughenbaugh ${ }^{1,2,+}$, Idan Kahnonitch ${ }^{3,4,+}$, Charles C. Carey ${ }^{2}$, Alexander J. McMenamin ${ }^{2,5}$, \\ Tanner Wiegand ${ }^{2}$ (D), Tal Erez ${ }^{6}$, Naama Arkin ${ }^{4,7}$, Brian Ross ${ }^{1,2}$, Blake Wiedenheft ${ }^{5}$, Asaf Sadeh ${ }^{4}$ (D), \\ Nor Chejanovsky ${ }^{6}$ (D), Yael Mandelik ${ }^{3}$ and Michelle L. Flenniken ${ }^{1,2,5, *}$
}

check for updates

Citation: Daughenbaugh, K.F.; Kahnonitch, I.; Carey, C.C.;

McMenamin, A.J.; Wiegand, T.; Erez, T.; Arkin, N.; Ross, B.; Wiedenheft, B.; Sadeh, A.; et al. Metatranscriptome Analysis of Sympatric Bee Species Identifies Bee Virus Variants and a New Virus, Andrena-Associated Bee Virus-1. Viruses 2021, 13, 291. https://doi.org/10.3390/v13020291

Academic Editor: Eugene V. Ryabov

Received: 30 December 2020

Accepted: 3 February 2021

Published: 12 February 2021

Publisher's Note: MDPI stays neutral with regard to jurisdictional claims in published maps and institutional affiliations.

Copyright: (c) 2021 by the authors. Licensee MDPI, Basel, Switzerland. This article is an open access article distributed under the terms and conditions of the Creative Commons Attribution (CC BY) license (https:// creativecommons.org/licenses/by/ $4.0 /)$.
1 Department of Plant Sciences and Plant Pathology, Montana State University, Bozeman, MT 59717, USA; kdaughenbaugh@gmail.com (K.F.D.); brian.ross6@student.montana.edu (B.R.)

2 Pollinator Health Center, Montana State University, Bozeman, MT 59717, USA; charlieccarey@gmail.com (C.C.C.); alexmcmenamin2@gmail.com (A.J.M.); tnrwgnd@gmail.com (T.W.)

3 The Faculty of Agriculture, Food and Environment, The Hebrew University of Jerusalem, Rehovot 5290002, Israel; idan.kanonitch@mail.huji.ac.il (I.K.); yael.mandelik@mail.huji.ac.il (Y.M.)

4 Agroecology Lab, Newe Ya'ar Research Center, ARO, Ramat Yishay 30095, Israel; naamaark@gmail.com (N.A.); asafsa@volcani.agri.gov.il (A.S.)

5 Department of Microbiology and Immunology, Montana State University, Bozeman, MT 59717, USA; bwiedenheft@gmail.com

6 Entomology Department, ARO, The Volcani Center, Rishon Lezion 7528809, Israel; tal.erez2@mail.huji.ac.il (T.E.); ninar@volcani.agri.gov.il (N.C.)

7 The Mina \& Everard Goodman Faculty of Life Sciences, Bar Ilan University, Ramat Gan 5290002, Israel

* Correspondence: michelle.flenniken@montana.edu; Tel.: +1-406-994-7229

+ These authors contributed equally to this work.

Abstract: Bees are important plant pollinators in agricultural and natural ecosystems. High average annual losses of honey bee (Apis mellifera) colonies in some parts of the world, and regional population declines of some mining bee species (Andrena spp.), are attributed to multiple factors including habitat loss, lack of quality forage, insecticide exposure, and pathogens, including viruses. While research has primarily focused on viruses in honey bees, many of these viruses have a broad host range. It is therefore important to apply a community level approach in studying the epidemiology of bee viruses. We utilized high-throughput sequencing to evaluate viral diversity and viral sharing in sympatric, co-foraging bees in the context of habitat type. Variants of four common viruses (i.e., black queen cell virus, deformed wing virus, Lake Sinai virus 2, and Lake Sinai virus NE) were identified in honey bee and mining bee samples, and the high degree of nucleotide identity in the virus consensus sequences obtained from both taxa indicates virus sharing. We discovered a unique bipartite + ssRNA Tombo-like virus, Andrena-associated bee virus-1 (AnBV-1). AnBV-1 infects mining bees, honey bees, and primary honey bee pupal cells maintained in culture. AnBV-1 prevalence and abundance was greater in mining bees than in honey bees. Statistical modeling that examined the roles of ecological factors, including floral diversity and abundance, indicated that AnBV-1 infection prevalence in honey bees was greater in habitats with low floral diversity and abundance, and that interspecific virus transmission is strongly modulated by the floral community in the habitat. These results suggest that land management strategies that aim to enhance floral diversity and abundance may reduce AnBV-1 spread between co-foraging bees.

Keywords: honey bee virus; Apis mellifera; Andrena; virus transmission; RNA virus; Andrenaassociated bee virus-1 (AnBV-1); Lake Sinai virus; black queen cell virus; deformed wing virus; bees; pollinators; virus ecology 


\section{Introduction}

Bees gather plant-produced pollen and nectar as their protein and carbohydrate sources, respectively, and in doing so provide a critical ecosystem service- the pollination of numerous plant species. Approximately $87.5 \%$ of flowering plants benefit from animal-mediated pollination, including bees [1]. Bee-pollinated plants include those that produce fruit, nut, and vegetable crops, with a global annual value of $\$ 175$ billion dollars (USD) [2]. There are over 20,000 known bee species worldwide [3]. Bees differ in many life-history traits including diet breadth (i.e., specialist or generalist foragers based on their preference or lack thereof for particular plants); sociality, ranging from solitary to eusocial; nesting habits, including ground, cavity, and open nesting; activity season; body size and proboscis length [3-5], and related flight distance [6]. These traits influence their nutritional requirements, ability to adapt to land-use changes and climate change, and their susceptibility to pathogens.

In many parts of the world, insect populations have declined [7]. These losses are attributed to multiple factors including habitat destruction, insecticide exposure, the loss of quality nutritional resources, climate change, parasites, and pathogens [8-11]. In particular, many bee populations have suffered range reductions and local extinction, including the rusty patched bumble bee (Bombus affinis) and the western bumble bee (Bombus occidentalis) in the US [12-14]. The factors influencing bee population declines vary geographically. In some parts of the world, local bee populations have expanded in part due to management practices (e.g., an increased number of managed Apis mellifera colonies in Argentina and Spain), or have altered occupancy patterns due to climate change and/or urbanization [15-17]. Regardless of population trends, insects in general ( $>1$ million species) and bees in particular remain greatly understudied [18].

Although the majority of bee taxa are under-researched, honey bees (Apis mellifera) are one of the most studied insects due to their wide global distribution and their importance in agriculture. Honey bees are eusocial insects that live in colonies of $\sim 30,000$ individuals. Colonies are composed of predominantly sterile female workers, one reproductive female (the queen), and hundreds of seasonal males (drones) [19]. Beekeepers manage honey bee colonies for honey production and pollination services. Honey bees forage across longer distances (i.e., typically within two kilometers, but up to $10 \mathrm{~km}$ from their hive) compared to most other bee species [20-22].

They are generalist foragers that readily visit and pollinate a wide variety of crops and wild flowers. These traits, coupled with the ability to transport managed hives to pollinate many crops, have increased agricultural reliance on migratory beekeeping operations. This is particularly true in the US, where large-scale monoculture is common practice, but also in other parts of the world, including Israel, which has one of the highest beekeeping densities in the world (i.e., 10,000 hives per 7,000 $\mathrm{km}^{2}$ ) [23]. High annual losses of managed honey bee colonies in many parts of the world (e.g., 37\% average annual loss in the United States from 2010 to 2018 and up to $40 \%$ in Israel in 2008) [23-33] have heightened the scientific and public interest in the abiotic and biotic factors contributing to these losses and the ecological importance of all bee taxa, including native and/or wild bees such as mining bees.

Mining bees include over 1550 species in the genus Andrena (Andrenidae) [3,34]. These wild bees have a mostly Holarctic distribution [35] and are commonly found in both agricultural and wild landscapes. Bees in this genus are generally solitary and lack social structures, although some species are communal [3,36,37]. Unlike honey bees, all Andrena females can produce offspring, which they must provide nutritional resources, since there is no division of labor or overlap of generations [37]. Andrena species persist on a nectar and pollen diet and show a wide range of foraging behaviors from generalist (broadly polylectic, exploiting multiple plant families) to highly specialist (narrow oligolectic, foraging on a single plant genus) $[38,39]$. While adults of many species are usually only active for several weeks per year, oligolectic species time their emergence to coincide with the flowering 
period of preferred host plants [39]. In the Mediterranean and semi-arid eco-regions of Israel, Andrena species are prevalent [35].

High average annual losses of honey bee (Apis mellifera) colonies and regional population declines of some mining bee species (Andrena spp.) are attributed to multiple factors including habitat loss, lack of quality forage, insecticide exposure, and pathogens. Bee pathogens include bacteria, fungi, microsporidia, and numerous viruses [40-43]. The majority of research investigating the impact of viruses on bee losses has been carried out in honey bees, due to their importance as agricultural pollinators, their well-known biology and behavior, and the fact that they are managed and readily reared and manipulated at the individual and colony scale. Therefore, most bee-associated viruses are known as "honey bee viruses" in recognition of the host from which they were first discovered and described (reviewed in $[42,44]$ ). Most of the characterized bee-infecting viruses are positive-sense, single-stranded RNA viruses (+ssRNA) in the Picornaviridae family including Dicistroviruses (acute bee paralysis virus (ABPV), black queen cell virus (BQCV), Israeli acute paralysis virus (IAPV), and Kashmir bee virus (KBV)); the Iflaviruses (deformed wing virus (DWV), Kakugo virus, Varroa destructor virus-1/DWV-B, sacbrood virus (SBV), and slow bee paralysis virus (SBPV)); and taxonomically unclassified viruses (chronic bee paralysis virus (CBPV) and the Lake Sinai viruses (LSVs)) (reviewed in [42,45]). There are very few identified bee-infecting viruses with DNA genomes, which include Apis mellifera filamentous virus (AmFV) [46,47] and Osmia cornuta nudivirus [48,49]. Several honey bee-associated viruses have been detected in wild bee species including BQCV, LSV, SBV, and AmFV in Andrena vaga, and LSV and AmFV in Andrena ventralis in Belgium [50], and DWV, BQCV, and SBV in Andrena spp. sampled in the eastern United States [48,51-56]. It is unclear whether virus detections in most of these studies were indicative of active infections in mining bees since viral replication was not assessed by negative strand-specific RT-PCR or inferred by quantitative PCR, though DWV replication was detected in Andrena haemorhoa in Germany [57].

Recent high-throughput sequencing studies identified additional honey bee-infecting +ssRNA viruses including Bee macula-like virus (BeeMLV) in the Tymoviridae family, Apis mellifera flavivirus, and Apis mellifera nora virus 1 [58,59], as well as the first negativesense single-stranded RNA viruses (-ssRNA) including Apis mellifera rhabdovirus-1 (ARV-1) [59], also known as Bee rhabdovirus (BRV-1) [60] and Apis mellifera rhabdovirus-2 (ARV-2) (reviewed in [43]). To date, the majority of sequencing efforts aimed at identifying bee-associated viruses have utilized honey bee and the ectoparasitic mite (Varroa destructor) samples [48,59-63] (reviewed in [43]). Sequencing a greater variety of bee and other insect species indicates that many honey bee-infecting viruses have a broader host range that includes bumble bees (Bombus spp.), ants (Camponotus spp.) [64,65], and wasps (Polistes fuscatus and Vespula vulgaris) $[56,64,66]$. Schoonvaere et al. utilized highthroughput sequencing to detect previously characterized bee viruses and identify new virus and virus-like sequences associated with eight wild bee species, including three mining bee species-Andrena cineraria, Andrena fulva, Andrena haemorrhoa; three bumble bee species-Bombus terrestris, Bombus cryptarum, Bombus pascuorum; and two mason bee species-Osmia bicornis, and Osmia cornuta, collected from four locations in Belgium [49]. Overall, the normalized virus coverage data indicate that the majority of previously described bee viruses were not detected in this sample cohort. Likewise, incomplete genome coverage of detected viruses, including new putative virus-like sequences, suggests low virus abundance, though this result may be in part due to the use of polyA-based sequence libraries. For example, relatively few BQCV and DWV-B/VDV-1 reads were detected in $B$. terrestris and B. cryptarum, and B. terrestris and O. cornuta, respectively, suggesting either low/initial infection levels or detection of pollen-associated virus $[49,51,56]$. Furthermore, this study revealed that the viruses detected varied with sample site and bee taxa, indicating that viruses are not necessarily shared between co-foraging bee species. For example, Bee macula-like 2 virus was abundant in A. haemorrhoa samples, but absent from other bee samples, within a single site [49]. Identification of 11 new virus-like sequences in 
this study, including putative negeviruses, which were detected in numerous samples, suggests that additional sequencing studies are required to identify the complete suite of bee-infecting viruses. Moreover, studies that characterize bee-associated viruses are needed to confirm that virus-like sequences are bona fide viruses. Follow up studies that examine the prevalence and abundance of recently identified viruses in bees and other insects are also required to better understand the ecology of bee/insect-infecting viruses, including determining which viruses negatively impact bee communities.

Virus transmission within species occurs vertically from parents to offspring. Horizontal transmission within species occurs through several mechanisms including close contact, especially among eusocial colony-dwelling insect species and via behaviors such as trophallaxis (mouth-to-mouth food transfer) and grooming. Horizontal virus transmission, both within and between honey bee colonies, includes vector-mediated transmission (reviewed in [42,67]). For example, the Varroa destructor mites that parasitize honey bee colonies can be productively infected by several bee viruses (e.g., DWV [68-71], IAPV [72], KBV [73], and CBPV [74]). Viruses are transmitted to bees within and between honey bee colonies when infected mites feed on bees. Wax moths (Galleria mellonella) and small hive beetles (Aethina tumida) are other honey bee colony infesting insects that can host active IAPV and BQCV, and DWV infections, respectively [75-79]. It is likely that these insects host additional bee-infecting viruses. Carnivorous wasp and ant species can also be productively infected by DWV, IAPV, and BQCV $[65,80]$. Though commonly described as "bee virus" infections in other insects, virus transmission between parasitic insects and their hosts is bidirectional.

The most prevalent route of virus transmission between different bee taxa is likely via shared floral resources [53,56,81-87]. Specifically, infected bees can deposit viruses on flowers as they forage, and these viruses can then infect other bees that visit these flowers. Clear experimental based evidence of interspecies transmission was demonstrated in greenhouse studies of IAPV-transmission from honey bees to bumble bees and vice versa via shared food resource [56]. However, co-foraging species do not necessarily share viruses, as demonstrated by deposition of BQCV and DWV onto floral resources by honey bees, and lack of infection in bumble bees that foraged on the same flowers [53] and lack of virus infection via oral inoculation [88]. At the community level, interspecies virus transmission in sympatric honey bees and bumble bees was indicated by the extent of virus sequence identity in both taxa [87]. Directionality of infections is often inferred based on the prevalence and abundance of viruses in particular species within a sample cohort $[52,87]$. However, it is important to note that studies based on sample cohorts obtained at a single snapshot in time and/or from a single geographic location may not accurately represent virus ecology, as virus infections in honey bee colonies vary with sample date [89-94]. Thus, longitudinal studies with large samples sizes and/or the cumulative evidence from numerous smaller-scale studies are required to document biologically important trends. Examples of such studies include those that documented high DWV prevalence and abundance in the fall, coupled with high Varroa mite infestation correlate with over-winter honey bee colony death $[69,89,91,95,96]$.

Evidence indicating that virologists, entomologists, and ecologists are in the initial phases of characterizing the bee-associated virome is provided in a recent study that sequenced virus-augmented samples from honey bees obtained as part of a large-scale sampling effort in Belgium, coupled with in-depth analyses of existing sequence data [97]. The study by Deboutte et al. not only resulted in the discovery of new virus-like sequences, virus strains, and potential recombinant viruses in honey bees, it also included bioinformatic analyses of over 5000 sequence datasets, which revealed that a high number of viral genomes were common to numerous Apidae family members, as well as widely distributed across different families within the order Hymenoptera [97]. These results, coupled with smaller-scale studies documenting virus replication in species beyond that of the host(s) from which particular viruses were discovered, suggest that many Hymenopteran viruses, and likely insect viruses in general, infect a wide range of species, and thus the concepts of 
species-specific viruses and paradigm of "spillover" from honey bees to other bee species should be reevaluated [97].

To evaluate virus diversity and prevalence in sympatric, co-foraging bee species, and to identify ecological factors that are associated with patterns of virus spread, we conducted a field survey across 14 sites in Israel within a single blooming season, sampling populations of honey bees and dominant mining bee species. From these samples, we identified beeassociated viruses using high-throughput sequencing, including viral genome variants of BQCV, DWV, LSV-2, and LSV-NE, which would likely escape detection with the use of widely adopted primer sets that were developed based on virus sequences obtained from North America and Europe. Sequencing efforts resulted in the discovery of a unique bipartite +ssRNA Tombo-like virus. This virus was very prevalent and abundant in Andrena samples and therefore named Andrena-associated bee virus-1 (AnBV-1). AnBV-1 was also detected in honey bee samples albeit at lower frequency and abundance. Statistical modeling indicated that the probability of AnBV-1 infection in honey bees was greater in habitats with low floral diversity and abundance, suggesting that interspecific virus transmission is strongly modulated by the floral community in the habitat. Laboratory based experiments were carried out to confirm that AnBV-1 is a bona fide virus that replicates in primary honey bee pupal cells maintained in culture. There is a dearth of bee viruses that can be studied in the lab, and therefore future development of AnBV-1 may result in a new experimentally tractable system for investigating bee host-virus interactions. These studies are essential to understanding the impact of viruses on bees.

\section{Materials and Methods}

\subsection{Study Region and Survey Design}

We conducted a field survey during March 2018 in the Judean Foothills, central Israel, a Mediterranean agro-ecosystem comprised of a mosaic of agricultural fields, planted forests, and shrublands. Honey bees are commonly managed in this region for crop pollination and honey production. Previous studies in this region revealed diverse and abundant wild bee communities in both agricultural fields and surrounding natural and semi-natural habitats $[98,99]$. The survey included a total of fourteen sites (Figure 1 and Supplementary Table S1); sites were patches of wild bloom dominated by yellow-flowering Brassicaceae species, mainly Sinapis alba, Hirschfeldia incana, and Rapistrum rugosum. The average distance between neighboring sites was $1914 \mathrm{~m}$, ranging between 524 and $4960 \mathrm{~m}$. Eight of the sites were characterized by up to six blooming floral species (that were seen visited by bees during the survey), and classified as low-floral-diversity habitats. The other six sites, classified as high-floral-diversity habitats, were characterized by having greater than nine blooming floral species (that were seen visited by bees during the survey), including families other than Brassicaceae. While this initial classification of the sites to high and low floral diversity was performed for the purpose of site selection, subsequent characterization of each site was based on pollinator resource use and floral abundance data recorded at the site (Figure 6). 


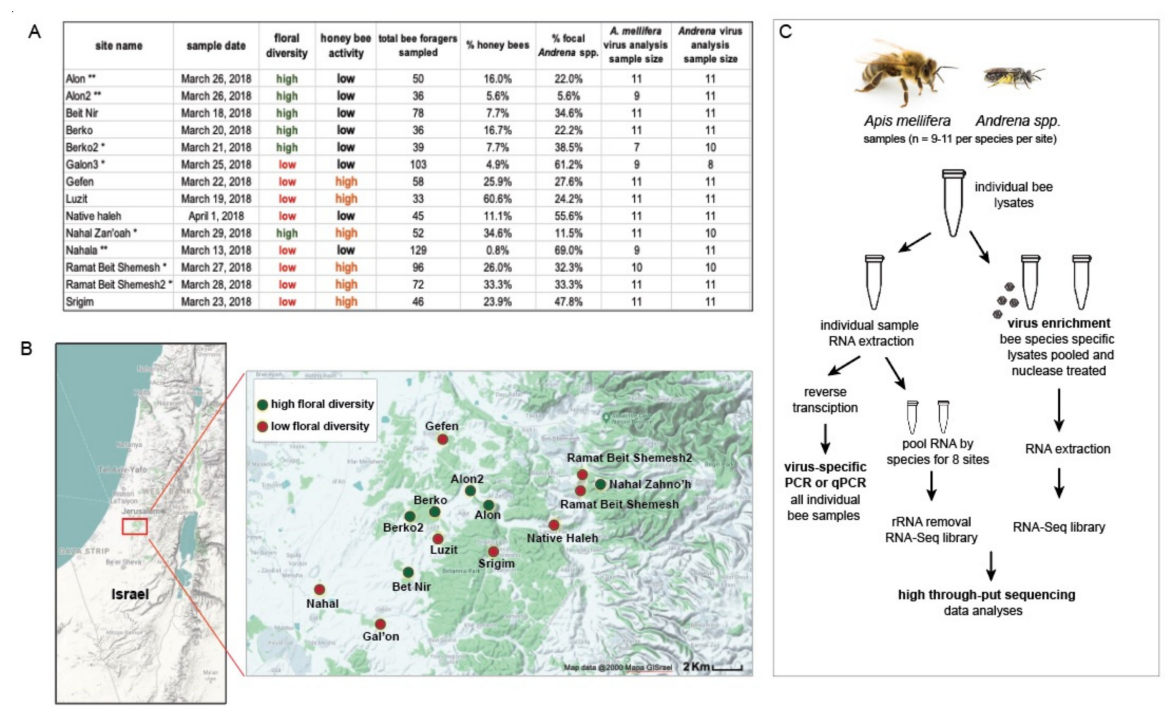

Figure 1. Overview of sampling and analysis of sympatric bee species collected from 14 sites in Israel. (A). The table provides a summary of the site-specific data obtained in this 2018 sample cohort. Sampling sites were selected for the survey as either high or low floral diversity, based on their floral species richness. Honey bee activity at each site was also categorized as either high or low, based on the percentage of honey bees out of the total number of bees sampled. This study resulted in the collection of over 1331 bee samples, including 263 Apis mellifera and 876 Andrena spp. samples. Assessment of viral diversity and abundance was carried out on a subset of individual bees (i.e., a median of 11 individual bees per taxon per site). (B). Map of Israel with sample sites labeled and marked with green and red dots indicating high and low floral diversity, respectively. (C). Schematic of the sample sizes and molecular analyses.

Each site was sampled for one day, from 8:00 to 16:00. Sampling was conducted only during favorable weather conditions (temperature $>17^{\circ} \mathrm{C}$, wind velocity $<3 \mathrm{~m} / \mathrm{s}$, and clear or partially clear skies). In each site, we marked a 25 by $25 \mathrm{~m}$ plot where sampling of bee foraging activity and of the floral community was carried out. The bee foraging activity sampling was conducted by slowly walking throughout the plot and netting bees from flowers for $40 \mathrm{~min}$ (excluding bee handling time). Each captured bee was identified in situ to the lowest taxonomic level possible, immediately placed in a separate vial, and kept on dry ice. The visited flower species of each captured bee was recorded. At the end of each sampling day, all the collected specimens were transported to the lab and stored at $-80^{\circ} \mathrm{C}$.

To sample the floral community in each site, we sampled each plot by randomly placing ten $1 \mathrm{~m}$ radius hoops. In each hoop, we identified all the flowering species and counted the abundance of each species' distinct floral units. We defined distinct floral units for most taxa as individual flowers or distinct florets within sparse inflorescences. In Compositae, Umbelliferae and Trifolium, floral units were defined as individual inflorescences. To account for the large surfaces of inflorescences in these families, we multiplied their counts by their surface size relative to that of dominant single flowers in the field.

The studied region is generally characterized by a patchy, fine-grained land-use mosaic, in which wild flower patches are relatively similar to each other in terms of the floral community (verified visually during site selection). Therefore, each of our sampled plots well represented the flower patches in the broader area, in a radius of at least several hundreds of meters.

Virus Analysis

The two most abundant bee taxa in this sample cohort were mining bees (i.e., genus Andrena; A. combusta ochraceohirta, A. aerinifrons levantina, A. urfanella and an unidentified morphospecies of the subgenus Truncandrena) and honey bees (Apis mellifera). Therefore, virus identification efforts were focused on these two bee taxa. A subset of the samples 
(i.e., between 7 and 11 individuals, with a median number of 11 individuals) per taxa per site were used for virus identification via high-throughput sequencing, and subsequent determination of the prevalence and abundance of AnBV-1. The first round of sequencing was carried out on sequencing libraries representing each bee species (i.e., pooled Apis mellifera or Andrena spp. samples) obtained from the following sites: Galon3-low floral diversity, low relative $A$. mellifera activity; N. Zanoah-high floral diversity, high relative A. mellifera activity; R.B.Sh-low floral diversity, high relative A. mellifera activity; and Berko2-high floral diversity, low relative A. mellifera activity (relative honey bee activity per site was categorized as high/low for sites with more/less than $20 \%$ honeybee foragers, out of the total number of sampled bees, respectively). In addition, sequencing libraries were prepared from two virus-augmented samples, as described below. To identify the most prevalent and abundant viruses in additional sites from this study, a second round of sequencing was carried out on pooled virus-augmented samples from each species (i.e., Apis mellifera or Andrena spp.) obtained from the following sites: Nahala-low floral diversity, low relative $A$. mellifera activity; Alon—high floral diversity, high relative $A$. mellifera activity; R.B.Sh2-low floral diversity, high relative A. mellifera activity; and Alon2-high floral diversity, low relative A. mellifera activity.

\subsection{RNA Extraction}

Individual bees in $2 \mathrm{~mL}$ safe-lock Eppendorf tubes were homogenized in $500 \mu \mathrm{L}$ sterile buffer (100 mM Tris, $100 \mathrm{mM} \mathrm{NaCl}$ Tris $\mathrm{pH} 7.6)$ using 2 tungsten balls $(2.85 \mathrm{~mm}$, Ultraparts) in a Geno/Grinder (Spex SamplePrep) at $1550 \mathrm{rpm}$ for $1.5 \mathrm{~min}$. Samples were centrifuged for $2 \mathrm{~min}$ at $13,500 \mathrm{rpm}$ at $4{ }^{\circ} \mathrm{C}$ to pellet debris. Supernatants (i.e., $150-200 \mu \mathrm{L}$ for Andrena spp. and $400 \mu \mathrm{L}$ for Apis mellifera) were transferred to a new tube and combined with 1-2 volumes of Trizol reagent (Life Technologies), vortexed, and incubated at room temperature for $5 \mathrm{~min}$. Next, $150 \mu \mathrm{L}$ of chloroform was added and each sample was mixed by hand for $15 \mathrm{~s}$, followed by incubation at room temperature for $3 \mathrm{~min}$. Samples were centrifuged for $15 \mathrm{~min}$ at $12,000 \times \mathrm{g}$ at $4{ }^{\circ} \mathrm{C}$, and the aqueous phase was removed from each sample and transferred to a fresh tube. An equal volume of isopropanol was added to each sample, along with $20 \mu \mathrm{g}$ glycogen to aid in precipitation. Samples were precipitated at $-20^{\circ} \mathrm{C}$ for $24-72 \mathrm{~h}$, then centrifuged for $10 \mathrm{~min}$ at $12,000 \times \mathrm{g}$ at $4{ }^{\circ} \mathrm{C}$. Supernatants were carefully removed by pipetting, and each pellet was washed twice with $75 \%$ ethanol. Final pellets were air dried at room temperature for $15 \mathrm{~min}$, then dissolved in 20-30 $\mu \mathrm{L}$ sterile distilled water. RNA was quantified by spectrometry using a NanoDrop instrument (ThermoFisher). RNA samples of poor quality, where A260/A280 <1.7, were re-precipitated with lithium chloride or sodium acetate by combining the sample with an equal volume of isopropanol containing $700 \mathrm{mM} \mathrm{LiCl}$ or $1.5 \mathrm{M} \mathrm{NaOAc}$, and precipitated at $-20^{\circ} \mathrm{C}$ for $1.5 \mathrm{~h}$. RNA was washed with $75 \%$ ethanol as before and suspended in sterile distilled water. All RNA samples were stored at $-80^{\circ} \mathrm{C}$ until analysis.

\subsection{RNAseq Library Preparation and Sequencing}

RNA was sent to the Roy J. Carver Biotechnology Center at the University of Illinois for library preparation (Illumina TruSeq Stranded RNA Sample Prep kit) and paired-end sequencing on Illumina HiSeq 4000 or MiSeq sequencing systems. Libraries were prepared and quantitated using an Illumina Library quantification kit (Kapa). Paired end sequencing libraries were generated according to manufacturers' instructions (lllumina). In brief, RNA from individual bees ( $n=11$ per library) was pooled to generate sequencing libraries representing each bee species (i.e., Apis mellifera or Andrena spp.) obtained from four sites (i.e., Galon3, N. Zanoah, RBSh, and Berko2), resulting in a total of eight sequencing libraries. The goal of sequencing these eight samples was to sequence bee-associated viruses (genomes/transcripts). Therefore, ribosomal RNA (rRNA) was depleted using the Ribo-Zero-Gold (Human/Mouse/Rat), which is compatible with Apis mellifera rRNA and Andrena spp. rRNA, which is very similar to honey bee rRNA ( $92 \%$ identical, e $=0$ ), prior to the preparation of the libraries. Each of the libraries were paired-end sequenced on a 
HiSeq 4000 using a HiSeq 4000 SBS sequencing kit version 1, yielding 44 million reads $(2 \times 100 \mathrm{nt})$ per sample.

In addition, the first round of sequencing included two virus-augmented libraries (i.e., one library representing Apis mellifera $(n=44)$ and one library representing Andrena spp. $(n=44)$, pooled from the four sites mentioned above) were prepared as follows. To enhance the amount of viral RNA sequenced, bee lysates were augmented for virionprotected/encapsidated nuclease treated by mixing $150 \mu \mathrm{L}$ bee lysate with $50 \mathrm{U}$ Benzoase (Sigma) and $40 \mathrm{U}$ RNase I (Thermo) in total reaction volume of $250 \mu \mathrm{L}$, incubated at $37^{\circ} \mathrm{C}$ for $1.5 \mathrm{~h}$, then extracted with Trizol reagent (Thermo) according to the manufacturer's instructions. Glycogen (Thermo) was added at a concentration of $20 \mu \mathrm{g}$ per sample to aid in nucleic acid precipitation. Illumina paired-end $100 \mathrm{bp}$ libraries were prepared without polyA selection (since not all virus genome segments are poly-adenylated) or rRNA removal steps since presumably the majority of rRNAs and the cytoplasmic mRNAs would have been degraded by RNAse treatments. RNA quality and abundance were estimated by NanoDrop and Qubit, which indicated very low abundance of RNA in virus-augmented samples. Reverse transcription was primed using random hexamers, followed by second strand synthesis, and amplification. Sequencing was as described above (HiSeq 4000) except that these virus-augmented libraries were diluted such that they would account for only $5 \%$ of the total sequencing lane capacity. Sequencing was on a single HiSeq 4000 lane, in combination with the above mentioned eight samples and yielded $\sim 12$ million reads $(2 \times 100 \mathrm{nt})$ for each of these virus-augmented samples.

A second round of virus-augmented RNAseq was carried out similarly to the first round of virus-augmented samples, but with new pools for Apis mellifera $(n=44)$ and Andrena spp. $(n=44)$ from samples obtained from four additional sites (i.e., Alon, Alon2, RBSh, and Nahala). This second round was sequenced on an Illumina MiSeq and yielded $\sim 3.5$ million reads $(2 \times 250 \mathrm{nt})$ each.

To obtain additional sequence data for AnBV-1, lysate from a single mining bee with a high abundance of AnBV-1 (i.e., sample 13, Supplementary Table S6), was nuclease treated by mixing $150 \mu \mathrm{L}$ bee lysate with $50 \mathrm{U}$ Benzoase (Sigma) and $40 \mathrm{U}$ RNase I (Thermo) in total reaction volume of $250 \mu \mathrm{L}$, incubated at $37^{\circ} \mathrm{C}$ for $1.5 \mathrm{~h}$, then extracted with Trizol reagent (Life Technologies) according to the manufacturer's instructions. Glycogen (Thermo) was added at a concentration of $20 \mu \mathrm{g}$ to aid in precipitation. The RNA from this sample was prepared and sequenced identically to the round two virus-augmented samples. This individual sample was sequenced on an Illumina MiSeq and yielded $\sim 3$ million reads $(2 \times 250 \mathrm{nt})$.

\subsection{Apis mellifera (Honey Bee) Genome Alignment}

To remove as much bee genome sequence from the RNAseq libraries prior to analyses, sequences were aligned to the Apis mellifera genome (i.e, GCA_003254395.2_Amel_HAv3.1_ genomic.fna, downloaded from NCBI 2019-02-07).

\subsection{HoloBee Database Expansion (March 2019)}

To identify and group sequences in the RNAseq libraries that corresponded to previously sequenced honey bee-associated microbes and viruses, the HoloBee-barcode and HoloBee-mop databases were downloaded from (https://data.nal.usda.gov/dataset/ holobee-database-v20161) and split into virus and non-virus portions [100]. The virus database was supplemented to reflect numerous discoveries of bee-sample associated putative viral sequences (Supplementary Table S9) $[48,49,59,60,66]$. Reads and contigs were also aligned (HISAT2) and queried (BLAST, blastn, and dc-megablast) against the ref_viruses_rep_genomes database (11,015 sequences, downloaded from NCBI as a BLAST database 2019-03-24) and CLC de novo viral binned contigs from eight wild bee species [49] (567 contigs, fig share, https:/ / figshare.com/authors/Karel_Schoonvaere/4182034, downloaded 2019-02-01); Supplementary Table S10). 


\subsection{RNA Sequencing and Analyses}

RNAseq and viral sequencing resulted in a total of 379,840,320, $2 \times 100 \mathrm{nt}$ read pairs, and 10,222,370, $2 \times 250$ nt read pairs (see Supplementary Table S2). Reads were downloaded from DNA Services at University of Illinois at Urbana-Champaign. The reads were already trimmed of their $3^{\prime}$ adaptor sequences and barcode sequences that distinguished samples within the same lane. FastQC was used to view qualities both before and after further quality trimming with Trimmomatic-0.36 [101]. An example trimming reads on a macbook: java-jar /Applications/Trimmomatic-0.36/trimmomatic-0.36.jar PE-threads 8 read1.fastq.gz read2.fastq.gz read1.paired.fastq.gz read1.unpaired.fastq.gz read2.paired.fastq.gz read2.unpaired.fastq.gz ILLUMINACLIP:TruSeq3-PE-2.fa:2:10:10:6 LEADING:3 TRAILING:3 SLIDINGWINDOW:4:15 MINLEN:36.

Reads surviving trimming as pairs were aligned to the honey bee genome using HISAT2 [102]. The HISAT2 indexes were built: hisat2-2.1.0/hisat2-build "\$target.fasta", where "\$target.fasta" referred to the honey bee genome. To remove reads aligning to, for example, honey bee, HISAT2 was combined with gsed and samtools $(1.9)[102,103]$ to recover only the unaligned reads: hisat2-2.1.0/hisat2 -threads 6 -summary-file metrics.metrics - $x$ "\$target" -1 read1.fastq.gz -2 read2.fastq.gz I gsed ' $\backslash t \backslash(77 \backslash \mid 141 \backslash) \backslash t[*] / ! d^{\prime}$ I samtools sort $n$ -threads 4 I samtools fastq -threads 4 -1 new.R1.fastq -2 new.R2.fastq -, where "\$target" was the index built above (e.g., the HISAT2 index for honey bee). Reads that aligned to honey bee were thereby omitted from further analyses. If only one of the read mats aligned to honey bee, both mates were omitted.

A complete Andrena genome was not available and thus sequences obtained from Andrena samples were also aligned to the honey bee genome (to remove at least some Andrena reads). The number of reads for each sample that aligned to the honey bee genome varied for each sample, but averaged $\sim 54 \%$ for honey bee samples and $\sim 14 \%$ for Andrena samples (Supplementary Table S2).

The RNAseq library reads (sequences) that did not align to honey bee (i.e., neither mate in the pair aligned) were then aligned to non-viral sequences from the Holobee database (described above) and the Lotmaria passim (formerly known as Crithidia mellificae, sf) to identify and remove non-viral reads that aligned to sequences within the augmented honey bee holobiome [104]. The procedure was identical to removal of the honey bee aligned reads.

The remaining RNAseq paired-end reads (i.e., non-Apis mellifera, and with the holobee non-virus reads likewise removed) from each library were assembled into contigs using Trinityrnaseq v2.10.0 via a docker image (docker pull trinityrnaseq/trinityrnaseq, 2019 and 2020) on either a macbook pro or AWS EC2 instances (e.g., $\mathrm{m} 5 \mathrm{~d}$. $12 \times$ large with 48 GiB Memory, 192 vCPU). Libraries from each sample were separately assembled. Contig assessment and quantification were performed using scripts included with trinityrnaseq. An example running trinityrnaseq via docker on EC2: sudo docker run -rm -v'pwd': $p w d^{\prime}$ trinityrnaseq/trinityrnaseq Trinity-seqType fq -CPU 46 -max_memory 182 G-left 'pwd'/read1.fastq -right 'pwd'/read2.fastq-output 'pwd'/out_trinity.

For contig quantitation, we used the trinityrnaseq utility script, align_and_estimate_ abundance.pl, specifying kallisto as the aligner [105]. An example on a macbook: trinityrnaseq/util/align_and_estimate_abundance.pl-transcripts contigs.fasta-seqType fq-left read1.fastq.gz -right read2.fastq.gz - est_method kallisto -trinity_mode -prep_reference -output_dir out_ quant. At times, we added the parameter $-k m e r-s i z e=21$ to better align more variant reads. Kmer size of 21 was experimentally determined to balance the alignment of the most reads to viral transcripts, while minimizing alignment of possibly non-target reads. To create virus-level abundance (e.g., all BQCV), we added a mapping from all contigs to all virus groupings (as labeled by their BLAST results) and supplied that as a custom trans_map as an argument to align_and_estimate_abundance.pl using the -gene_trans_map option. In other words, where this script usually quantitates contigs on a trinity concept of gene, consolidating all the isoforms, we applied an organism name instead of gene, so that we could review summaries at the organism level. 
To identify candidate viral contigs, the assembled contigs were aligned to NCBI's BLAST nt database (downloaded 2020-05-26) and BLAST databases constructed from the candidate virus contigs of eight wild bee species using blastn and dc-megablast with NCBI's BLAST+ suite (versions 2.10.1) [49,106]. Likewise, DIAMOND (version 0.9.35 downloaded 2020-06-21) was used to align contigs to $\mathrm{nr}$ with taxonomy enabled (nr, prot.accession2taxid.gz and taxdmp.zip downloaded 2020-05-26) [107]. To build the DIAMOND database (database version 3): diamond makedb -in nr.gz-taxonmap prot.accession2taxid.gz -taxonnodes taxdmp/nodes.dmp -taxonnames taxdmp/names.dmp - $\mathrm{db}$ n. The DIAMOND preconfigured reporting fields were extended to include stitle, sscinames, staxids, sphylums, skingdoms. An example aligning contigs to $\mathrm{nr}$ with DIAMOND on an EC2 instance (48 CPUs, 192 GiB memory, and 900 GiB NVMe SSD Drives i.e., EC2 m5 d.12 xlarge instance): sudo diamond blastx-query contigs.fasta - $d b \mathrm{nr}$-sensitive -evalue 0.001 -max-target-seqs 1 -max-hsps 1 -index-chunks 1 -block-size 7 -log-outfmt 6 qseqid sseqid pident length mismatch gapopen qstart qend sstart send evalue bitscore stitle sscinames staxids sphylums skingdoms -o diamond_out.tsv. BLAST results were post-processed, to retain the top hit of any putative viral contig, provided that the viral contig was greater than or equal to $400 \mathrm{nt}$.

To quantify reads and create coverage maps of the viral genome sequence variants described herein, reads were aligned and counted using kallisto and resulting bam files manipulated with using Samtools $[103,105]$. More specifically, reads were aligned (using a kallisto index built with $-\mathrm{kmer}$-size $=21$, appropriate for more sensitive alignments in this dataset) to all the candidate viral contigs to estimate abundances. For example, to align as many reads as possible to individual contigs, such as AnBV-1 RNA1 or other selected contigs, we created kallisto indexes from fasta files containing single contigs in parallel parallel kallisto

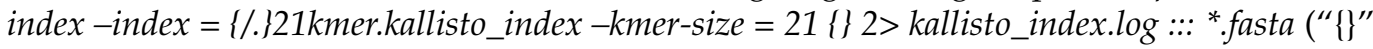
are placeholders for substitutions in parallel based on the glob "*" in *.fasta). Using those indexes, we aligned each sample to each individual contig to quantitate and to generate pseudobams for coverage maps, for example: kallisto quant -threads $=6$-pseudobam-outputdir index_name.sample_name -index kallisto_index_of_contig read1.fastq.gz read2.fastq.gz. Pseudobams were sorted and indexed using samtools. Read coverage was visualized by loading the indexed bam files into Integrative Genomics Viewer (IGV_MacApp_2.8.12_WithJava). RNAseq, Trinity assembly and BLAST analyses were performed on a Mid 2015 MacBook Pro (Quad-Core Intel Core I7, macOS 10.14-10.15) or high CPU and/or high Memory AWS EC2 instances (detailed above) with Amazon Linux AMIs. Job control, read counts, extracting, and relabeling candidate viral trinity contigs, etc., were performed using bash and R. Some examples within this section are simplifications. Detailed code is available at: https://github.com/charlieccarey/viral_transcriptome_of_bees.

\subsection{Reverse Transcription/cDNA Synthesis}

Reverse transcription (RT) reactions to produce complementary DNA (cDNA) were performed by incubating $300 \mathrm{ng}$ of RNA from each RNA pool or individual RNA sample with M-MLV reverse transcriptase (Promega) and 500 ng random hexamer primers (IDT) for $1 \mathrm{hr}$ at $37^{\circ} \mathrm{C}$ according to the manufacturer's instructions. Samples were diluted 1:1 with sterile distilled water prior to analysis.

\subsection{Polymerase Chain Reaction (PCR)}

PCR was performed according to standard methods [91,108]. In brief, $2 \mu \mathrm{L}$ cDNA template was combined with $10 \mathrm{pmol}$ of each forward and reverse primer, and amplified with $0.5 \mu \mathrm{L}(5 \mathrm{U} / \mu \mathrm{L})$ ChoiceTaq polymerase (Thomas Scientific) according to the manufacturer's instructions using the following cycling conditions: $95^{\circ} \mathrm{C}$ for $5 \mathrm{~min} ; 95^{\circ} \mathrm{C}$ for $30 \mathrm{~s}, 55^{\circ} \mathrm{C}$ for $30 \mathrm{~s}, 72{ }^{\circ} \mathrm{C}$ for $30 \mathrm{~s}-1 \mathrm{~min}, 35$ cycles; followed by final elongation at $72{ }^{\circ} \mathrm{C}$ for $4 \mathrm{~min}$. PCR products were visualized by $2 \%$ agarose gel electrophoresis and staining with SYBRsafe (Invitrogen). Positive and negative control reactions were included for all analyses and exhibited the expected results. Select products were purified with 
the Qiaquick PCR Purification Kit (Qiagen), quantified by NanoDrop spectrometry, and Sanger sequenced.

\subsection{Quantitative Polymerase Chain Reaction ( $q P C R$ )}

Quantitative PCR (qPCR) using primer sets listed in Supplementary Table S2 was utilized to quantify the viral RNA (i.e., genome and transcript) abundance in the samples. The specificity of virus-specific primer sets was confirmed through melt-point analysis, gel electrophoresis, and Sanger sequencing of select qPCR products. Primers for LSV (reverse primer only), BQCV, and AnBV-1 were designed based on the sequencing information obtained as part of this study. Importantly, qPCR analyses using previously described primers would have resulted in false-negatives since the viral consensus sequences described herein differed from previously reported virus strains.

All qPCR reactions were performed in triplicate using $2 \mu \mathrm{L}$ cDNA template (diluted 1:1 with sterile distilled water) per reaction. In addition, each $20 \mu \mathrm{L}$ qPCR reaction contained $1 \times$ ChoiceTaq Mastermix (Thomas Scientific), $0.4 \mu \mathrm{M}$ each forward and reverse primer, $1 \times$ SYBR green (Life Technologies), and $3 \mathrm{mM} \mathrm{MgCl}_{2}$. Reactions were carried out in 96-well plates using a CFX Connect Real-Time instrument using Maestro software (Bio-Rad) with the following thermo-profile: pre-incubation at $95^{\circ} \mathrm{C}$ for one minute; 40 cycles of $95{ }^{\circ} \mathrm{C}$ for $10 \mathrm{~s}, 60^{\circ} \mathrm{C}$ for $20 \mathrm{~s}$, and $72{ }^{\circ} \mathrm{C}$ for $15 \mathrm{~s}$; final extension at $72{ }^{\circ} \mathrm{C}$ for $1 \mathrm{~min}$, followed by melt curve analysis. Positive and negative control reactions were included for all qPCR analyses and exhibited the expected results.

Virus-specific qPCR-target amplicons were cloned into the pGEM-T (Promega) or pCR2.1TOPO (Life Technologies) vectors, as described previously [89]. Plasmid standards, containing $10^{3}$ to $10^{9}$ copies per reaction, were used as qPCR templates to assess primer efficiency and generate standard curves used for quantifying viral RNA copy numbers for each sample. Primer efficiencies were evaluated using qPCR assays of cDNA and plasmid dilution series, and calculated by plotting $\log _{10}$ of the concentration versus the crossing point threshold $(\mathrm{C}(\mathrm{t}))$ values and using the primer efficiency equation, $\left(10^{(1 / \text { Slope)-1 })} \times 100\right)$ [109]. The virus-specific qPCR primer sets utilized in this study had efficiencies ranging from 86 to $103 \%$ and provided accurate quantitative assessment of $>10^{3}$ RNA copies per reaction. The linear standard equations for virus-specific plasmid standards and qPCR primers listed in Supplementary Table S3 were as follows: $\mathrm{Rp} 18 \mathrm{Ct}=-3.937 \times$ $+40.506, \mathrm{R}^{2}=0.9982 ; \mathrm{LSV} C \mathrm{t}=-3.252 \times+39.697, \mathrm{R}^{2}=0.9979 ; \mathrm{DWV} \mathrm{Ct}=-3.4093 \times+41.641$, $\mathrm{R}^{2}=0.99756 ; \mathrm{AmFv} C \mathrm{t}=-3.3185 \times+39.489, \mathrm{R}^{2}=0.99151 ; \mathrm{BQCV} C \mathrm{t}=-3.2918 \times+40.332, \mathrm{R}^{2}$ $=0.99378 ; \mathrm{SBV} C \mathrm{t}=-3.725 \times+44.017, \mathrm{R}^{2}=0.99018 ; \mathrm{AnBV}-1 \mathrm{RNA} 1 \mathrm{Ct}=-3.5923 \times+42.246$, $\mathrm{R}^{2}=0.99893$; AnBV-1 RNA2 Ct $=-3.3896 \times+44.259, \mathrm{R}^{2}=0.94813$; negative strand AnBV-1 RNA1 C $t=-3.417 \times+40.427, R^{2}=0.9995$; negative strand AnBV-1 RNA2 C $t=-3.5973 \times$ $+44.846, \mathrm{R}^{2}=0.9972$. All reported $\mathrm{qPCR}$ data were normalized to genome copies per 100 ng RNA.

\subsection{Statistical Analysis of $q P C R$}

To test for differences in AnBV-1 RNA copies relative to the zero hour time point in honey bee pupal cells, base R version 3.3.3 was used to perform a pairwise Wilcoxon Rank Sums test with no multiple comparisons correction [110]. A Benjamini-Hochberg correction was performed to correct for increased rate of false positives for additional pairwise comparisons to the zero hour time point. Briefly, the $p$-values were ranked from lowest to highest, then each individual $p$-value's Benjamini-Hochberg critical value was calculated with the formula $(\mathrm{i} / \mathrm{m}) 0.25$, where " $\mathrm{I}$ " is the $p$-value's rank, $\mathrm{m}$ is the number of comparisons, and 0.25 is the false discovery rate. The largest $p$-value that was smaller than the critical value was considered as the cutoff for significance. Therefore, any $p$-value equal to or smaller than the cutoff was considered statistically significant and is indicated in each figure legend. 


\subsection{Negative Strand-Specific PCR}

AnBV-1-positive samples were analyzed for the presence of negative-strand RNA1 and RNA 2 using strand-specific RT-PCR according to published methods [111]. Briefly, RNA from select samples was extracted with Trizol as above, and cDNA synthesis reactions were performed with MMLV-RT (Promega) according to the manufacturer's instructions using negative strand-specific RNA 1 and RNA 2 primers (TAGS-AnBV-1-RNA1 and TAGS-AnBV-1-RNA2, respectively) tagged with an additional $21 \mathrm{nt}$ of sequence at their $5^{\prime}$ end. The TAGS sequence ( $5^{\prime}$ GGCCGTCATGGTGGCGAATAA3') shares no homology with AnBV-1 nor to the honey bee genome. In brief, $50 \mathrm{ng}$ RNA, relevant primer, and $0.5 \mathrm{mM}$ each dNTP were combined with RT Buffer containing 200 U MMLV-RT (Promega), and $40 \mathrm{U}$ RNaseOUT (Life Technologies). Reactions were incubated for $120 \mathrm{~min}$ at $37^{\circ} \mathrm{C}$, then unincorporated primers present in the RT reactions were digested with $2 \mathrm{U}$ exonuclease I (Life Technologies) per reaction at $37^{\circ} \mathrm{C}$ for $30 \mathrm{~min}$, followed by heat inactivation at $85^{\circ} \mathrm{C}$ for $5 \mathrm{~min}$. PCR was performed using $2 \mu \mathrm{L}$ of this cDNA template in $25 \mu \mathrm{L}$ reactions containing 10 pmol each of a tag-specific forward primer (TAGS) and an RNA 1 or RNA 2 reverse primer (AnBV-1-RNA1-R545 and AnBV-1-RNA2-R659, respectively) using the following cycling conditions: $95^{\circ} \mathrm{C}$ for $5 \mathrm{~min} ; 95^{\circ} \mathrm{C}$ for $30 \mathrm{~s}, 5{ }^{\circ} \mathrm{C}$ for $30 \mathrm{~s}, 72{ }^{\circ} \mathrm{C}$ for $30 \mathrm{~s}, 35$ cycles; final elongation $72{ }^{\circ} \mathrm{C}$ for $4 \mathrm{~min}$, hold at $12^{\circ} \mathrm{C}$. For negative controls, PCR was performed using template incubated in the absence of RT enzyme during the reverse transcription reaction, and with the reverse primer only. Positive controls included PCR with PCR primers (AnBV-1-RNA1-F366 and AnBV-1-RNA1-R545, and AnBV-1-RNA2-F461 and AnBV-1-RNA2-R659) for detection of RNA 1 and RNA 2, respectively. Self-priming was tested by performing reverse transcription reactions in the absence of exogenous primers, followed by PCR with qPCR primers as described above. PCR products were analyzed by $2 \%$ agarose gel electrophoresis and were stained with SYBR safe (Life Technologies).

\subsection{Rapid Amplification of cDNA Ends}

Rapid Amplification of cDNA Ends (RACE) was performed to extend the sequence of AnBV-1 RNA 1 and RNA 2 using the SMARTer RACE 5'/3' kit (Takara) according to the manufacturer's instructions. Briefly, RNA containing high amounts of AnBV-1 as determined by qPCR extracted from an individual Andrena spp. sample was used as template to make $5^{\prime}$ and $3^{\prime}$ RACE-ready cDNA products. Prior to making $3^{\prime}$ RACE ready cDNA approximately $500 \mathrm{ng}$ of RNA was polyadenylated using E. Coli Poly(A) Polymerase (New England Biolabs) according to the manufacturer's instructions, since RNAseq data indicated that neither RNA 1 nor RNA 2 were polyadenylated. PCR for the $5^{\prime}$ end of RNA 1 was performed using $5^{\prime}$ RACE-ready cDNA as template and primer AnBV-1-RNA1-R73. This PCR product was used as template for nested PCR using primer AnBV-1-RNA1-R43. The resulting PCR product was cloned using the In-Fusion system supplied with the RACE kit. Approximately 10-12 colonies were selected and grown in Leuria-Bertani broth supplemented with $100 \mu \mathrm{g} / \mathrm{mL}$ ampicillin and cultured overnight at $37^{\circ} \mathrm{C}$. Plasmid DNA was extracted using the Promega PureYield Plasmid Miniprep System (Promega). Plasmid DNA was sequenced using the M13R sequencing primer, and sequences were aligned to the corresponding consensus sequence obtained by RNAseq. PCR for the $3^{\prime}$ end of RNA 1 was performed using $3^{\prime}$ RACE-ready cDNA as template and primer AnBV-1-RNA1-F1862. This PCR product was used as template for nested PCR using primer AnBV-1-RNA1-F1972. PCR for the $5^{\prime}$ end of RNA 2 was performed using $5^{\prime}$ RACE-ready cDNA as template and primer AnBV-1-RNA2-R122. This PCR product was used as template for nested PCR using primer AnBV-1-RNA2-R69. PCR for the $3^{\prime}$ end of RNA 2 was performed using $3^{\prime}$ RACE-ready cDNA as template and primer AnBV-1-RNA2-F2572. This PCR product was used as template for nested PCR using primer AnBV-1-RNA2-F2612. All RACE products were cloned, sequenced, and aligned as described above. 


\subsection{Honey Bee Pupal Cell Cultures and AnBV-1 Infection}

Purple-eyed honey bee pupae were removed from the wax comb cells, in which they develop, using featherweight forceps (Bioquip). The pupae were incubated at $28^{\circ} \mathrm{C}$ overnight in 12-well plates. Damaged (i.e., melanized) pupae were discarded. Primary cells were harvested from surface sterilized honey bee pupae in a biosafety cabinet. Surface sterilization was carried out in a $50 \mathrm{~mL}$ conical tube in which pupae were swirled in $0.6 \%$ hypochlorite solution (diluted bleach) for $3 \mathrm{~min}, 70 \%$ ethanol for $3 \mathrm{~min}$, and in sterile water for injection (Gibco). In groups of two, pupae were dissected into head, thorax, and abdomen segments in $2 \mathrm{~mL} \mathrm{WH2}$ medium [112] in a $47 \mathrm{~mm}$ dish using sterile 18-gauge needles to vigorously disturb tissues and release cells into the medium. The cells were transferred to a $15 \mathrm{~mL}$ conical tube, while the carcasses were washed again with $2 \mathrm{~mL}$ of fresh medium, which was added to the same conical tube. Carcasses were then discarded. The total volume was brought to $14.5 \mathrm{~mL}$ with fresh WH2 medium, and $300 \mu \mathrm{L}$ of this cell suspension were plated into each well of a 48 well plate (approximately $10^{6}$ cells per well) and incubated at room temperature overnight before infection.

To infect cells with AnBV-1, $3 \mu \mathrm{L}$ Andrea spp. lysate containing 1.3-2.6 $\times 10^{8}$ copies AnBV-1 per $\mu \mathrm{L}$, or lysate without virus (mock), were added to each well of pupal cells and incubated at room temperature. To quantify virus abundance over the course of infection, RNA was isolated from cell culture wells on multiple days post-infection (dpi) (i.e., 0, 1, 2, $3,4,5$, or $7 \mathrm{dpi}$ ) using two volumes of Trizol reagent (Life Technologies) (i.e., $600 \mu \mathrm{L}$ per well) and pipetting to dislodge adherent cells and facilitate cell lysis. The entire contents of each well were transferred into $1.5 \mathrm{~mL}$ centrifuge tubes and RNA was extracted according to manufacturers' instructions as described above.

\subsection{Andrena-associated bee virus-1 (AnBV-1) Genome and Phylogenetic Analyses}

AnBV-1 open reading frames were predicted in SnapGene Viewer (www.snapgene. com) using the standard start codon option and using the Glimmer ORF finder tool in Geneious Prime (version 2020.2.3, www.geneious.com). Predicted ORF sequences and their translations were queried with BLAST and PHMMER online utilities [113,114]. AnBV1 ORF1 is $1740 \mathrm{nt}$ and encodes a putative 540 aa protein. Initial BLAST analyses (i.e., protein-protein BLAST (BLASTp) and Position-Specific Iterated BLAST (PSI BLAST) did not identify orthologous proteins and/or motifs in ORF1, ORF3, or ORF4. However, subsequent PHMMER analyses indicated that ORF2 of RNA1 encodes a 161 amino acid (aa) virion protein based on its similarity to a putative virion protein from spider-associated Loderio virus (NC_031748) [115]. AnBV-1 RNA 1 ORF2 shares $25.7 \%$ aa identity with Loderio virus ORF3, which is a 193 aa protein in the European Molecular Biology Laboratory database (EMBL-EBI), and both of these proteins fall into the SP24 (PF16504) family (Uniprot A0A1D9CFP5).

To construct a maximum likelihood phylogeny of viral RNA-dependent RNA polymerases (RdRp), 57 protein or polyprotein sequences were selected from a published list of insect and plant infecting viruses and were downloaded from NCBI (access data October 2020) [49]. These sequences were aligned using the LINSI option in MAFFT [116]. Columns composed of $\geq 80 \%$ gaps were removed from the alignment with Trimal before the alignment was manually inspected to remove sequences composed primarily of gapped positions [117]. ProtTest 3 was used to determine the best model for phylogenetic tree building and the alignment was used to construct a tree in PhyML with the BLOSUM62 + I + G model [118,119]. The resulting tree was rendered in FigTree [120]. GenBank accession numbers for either the $\mathrm{RdRp}$ sequences or the genome sequences from where the $\mathrm{RdRp}$ sequence obtained are as follows: Q9J5U7.1, BAU68080.1, NP_077730.1, YP_009160324.1, YP_009159826.1, YP_009143521.1, YP_009111338.1, YP_009032634.1, YP_009026384.1, YP_ 007761581.1, NP_042510.2, YP_003622540.1, YP_001718499.1, YP_001040002.1, NP_853560.2, YP_145791.1, YP_052864.1, NP_945134.1, NP_932306.1, NP_919040.1, NP_851403.1, NP_ 690806.1, NP_690839.1,NP_663297.1, NP_620648.1, NP_620564.1, NP_619751.1, NP_613283.1, NP_604464.1, NP_599247.1, NP_056825.2, NP_203553.1, NP_116487.1, NP_068549.1, NP_ 
066241.1, NP_037647.1, NP_049374.1, NP_044335.1, NP_041277.1, ASU47554.1, ANH71250.1, CAB95006.3, AFR34027.1, ACU32794.1, AEH26189.1, AEH26193.1, QAY29244.1, YP_009552019.1, YP_009337113.1, QED21532.1, ANG56339.1, YP_009336934.1, AZS32325.1, YP_009333257.1, YP_009345113.1, YP_009337165.1.

\subsection{Statistical Modeling of AnBV-1 Prevalence in the Field}

To explain the prevalence of AnBV-1 in honey bees, we used three explanatory variables: (1) infected Andrena forager density, (2) the species diversity of floral resources utilized by honey bees in the habitat, and (3) the abundance of floral species that were shared between Andrena and honey bees in each site (scaled to 10,000 floral units to enable model convergence). Infected Andrena forager density was estimated for each site using the proportion of virus-positive Andrena individuals from the virological sample (median $n=11$ per site), multiplied by the number of Andrena individuals collected in the bee forager sampling. The diversity of floral resources utilized by honey bees in each site was calculated using the Shannon diversity index, weighing species abundances based on their relative utilization by honey bees, as observed across all sites in the survey.

We used package lme4 in $\mathrm{R}$ version 4.0.3 to fit the data with generalized linear mixed effect models (GLMMs) with binomially-distributed errors and logit link functions [110,121]. The infection status (AnBV-1 present/absent) of individual honey bees was used as the response variable. The saturated model included all three explanatory variables, and the interaction term between infected Andrena density and shared flower abundance. Sites were included in all models as a random intercept factor. We also fitted reduced forms of the saturated model, as well as a null model that included only the site random factor. All models were ranked by their AICc scores using package bbmle [122]. The model with the lowest AICc score was selected as the best model and used for inference, and any model with $\triangle \mathrm{AICc}>2$ was considered significantly weaker. The overall significance of the best model is represented by its $\triangle \mathrm{AICc}$ from the null. Model diagnostics were performed using package DHARM [123]. To exclude the possibility of spatial autocorrelation between adjacent plots (direct statistical testing is not possible in a sample of 14 sites [124]), we examined the distances between the three sites (Ramat Beit Shemesh 2, Luzit, and Srigim) that had the greatest AnBV-1 prevalence in honey bees, and found that they were far apart from each other $(11.5 \mathrm{~km}, 7.9 \mathrm{~km}$, and $4.4 \mathrm{~km})$ and beyond the typical $\sim 2 \mathrm{~km}$ foraging range of the majority of honey bee foragers) [22], whereas their five nearest sites (within $2 \mathrm{~km}$ ) had zero AnBV-1 prevalence in honey bees.

\section{Results and Discussion}

\subsection{Metatranscriptome Assessment of Viruses in Sympatric Bee Species}

To investigate the degree of virus overlap and transmission between sympatric bee species in different environments, we collected samples of foraging bees from 14 sites in Israel. These sites were classified as high or low floral diversity and high or low honey bee activity and sampled on a single date between 13 March and 1 April 2018 (Figure 1). Over 2323 bees were observed and 1331 were collected. The most predominant bee taxa were Apis mellifera (honey bees, $n=263$ ) and Andrena species, commonly known as mining bees $(n=876)$. Therefore, these bee taxa were the focus of our investigation (Figure 1 and Supplementary Table S1). The Andrena species in this study included A. combusta ocraceohirta, A. aerinifrons levantina, and A. urfanella, and an unidentified morphospecies of the subgenus Truncandrena. Distinct bee species may differentially contribute to interspecific virus spread. However, we considered these congeneric Andrena species as a single epidemiological population, because they are closely related phylogenetically and also share similar ecological niches with respect to phenology, dial activity, nesting habits, and diet. They are yellow mustard specialists, and we observed that greater than $96 \%$ of their floral visits were on Sinapis alba and Hirschfeldia incana.

The majority of honey bee-infecting viruses are single-stranded positive-sense RNA viruses (+ssRNA) (reviewed in [42-44]). To identify bee-associated viruses, RNA was 
extracted from 9 to 11 individual bees per taxon per site, and samples were pooled by bee taxon (i.e., Apis mellifera or Andrena spp.) for each of eight sites representing four distinct classifications including: low floral diversity and low honey bee activity, high floral diversity and high honey bee activity, high floral diversity and low honey bee activity, and low floral diversity and high honey bee activity. Ten species-specific sequencing libraries were generated from honey bees and mining bees obtained from eight representative sites (Figure 1). In addition, two virus-augmented libraries (one from Apis mellifera samples and one from Andrena spp. samples) were prepared and sequenced on an Illumina Hiseq (paired-end $200 \mathrm{nt}$ ) resulting in an average of 44.4 million reads per bee transcriptome library and 8 million reads per virus-augmented library (Supplementary Table S2, BioProject ID PRJNA687318 SRA files). The majority of reads in the A. mellifera sequencing libraries aligned to the A. mellifera genome (Amel_HAv3.1) and were removed from further analysis, as were any reads in the Andrena spp. libraries that aligned to the A. mellifera genome (Supplementary Table S2) $[125,126]$. The remaining reads (i.e., nonhoney bee) were then aligned to previously characterized honey bee virus and virus-like sequences [49,59,60,100,104,127-130] (Supplementary Tables S9 and S10). The most frequently detected viruses in these sequencing libraries included black queen cell virus (BQCV), deformed wing virus (DWV), sacbrood virus (SBV), the DNA virus Apis mellifera filamentous virus (AmFv), and members of the more sequence-divergent Lake Sinai virus group [111,131-133]. To facilitate discovery of previously unreported virus strains and virus-like sequences, sequence reads corresponding to non-viral pathogens, including the parasites Varroa destructor and Lotmaria passim (formerly known as Crithidia mellificae, strain sf), were removed $[100,104,130]$. The remaining sequences were de novo assembled into contiguous overlapping DNA segments (contigs) using Trinity [134]. The most abundant contigs were further characterized and described herein as a novel, bipartite, positive-sense single-stranded RNA virus, Andrena-associated bee virus-1 (AnBV-1, MW397640).

\subsection{Sequence Variants of Bee-Infecting Viruses: Black Queen Cell Virus, Deformed Wing Virus,} and Members of the Lake Sinai Virus Group

RNA viruses replicate using virally encoded RNA-dependent RNA polymerases (RdRp), which typically have higher error rates than DNA-dependent DNA polymerases and often lack proof-reading capabilities [135]. Therefore, an actively replicating RNA virus results in millions/billions of sequence variants, referred to as quasispecies [136-138]. The degree of variation that warrants a new virus strain is not well established for all viruses and thus the term "sequence variant" is often used to describe a sequence that differs from previously reported viral genomes.

To assess variation in this sample cohort, sequences corresponding to well-characterized honey bee-infecting viruses, including BQCV, DWV-A, DWV-B/VDV-1, SBV, and representative LSVs were binned following identification using BLAST and assembled into contigs [106]. Unique representative contigs were aligned to corresponding viral genome reference sequences in order to identify the most similar viral genome currently reported in the NCBI database, which was used as a scaffold for contig assembly. Consensus sequences that represent the majority sequences of the viral variants described herein (i.e., Israel-2018 variants) were deposited in the NCBI database.

This analysis revealed nucleotide differences in black queen cell virus, deformed wing virus, and Lake Sinai virus genomes that may have precluded reliable detection of these viruses using commonly employed primers, which were developed based on virus genome sequences obtained from other geographic locations (e.g., United States, Germany, Belgium, and China). Therefore, new qPCR primers were designed for future quantification of the relative virus abundance in honey bee and mining bee samples obtained in this study (Supplementary Table S3).

\subsubsection{Black queen cell virus}

The BQCV variant identified in this study, BQCV Israel-2018 (MW397638), shares the greatest percent nucleotide identity (i.e., $90 \%$ ) with a BQCV variant (MH267693) associ- 
ated with bees obtained in 2009 from mite-resistant honey bee colonies on the Island of Gotland, Sweden (Supplementary Figure S1) [139]. Nucleotide alignment of the consensus sequence identified herein revealed numerous single-nucleotide polymorphisms, which were avoided in GPCR primer design. The depth sequence coverage for BQCV Israel-2018 varied by site and was greatest in the Apis mellifera library generated from the Ramat Beit Shemesh (RBSh) site (i.e., up to 6601x coverage) (Figure 2). This sampling site was dominated by Hirschfeldia incana (Mediterranean mustard) and a high degree of honey bee activity (Figure 1 and Supplementary Table S1).

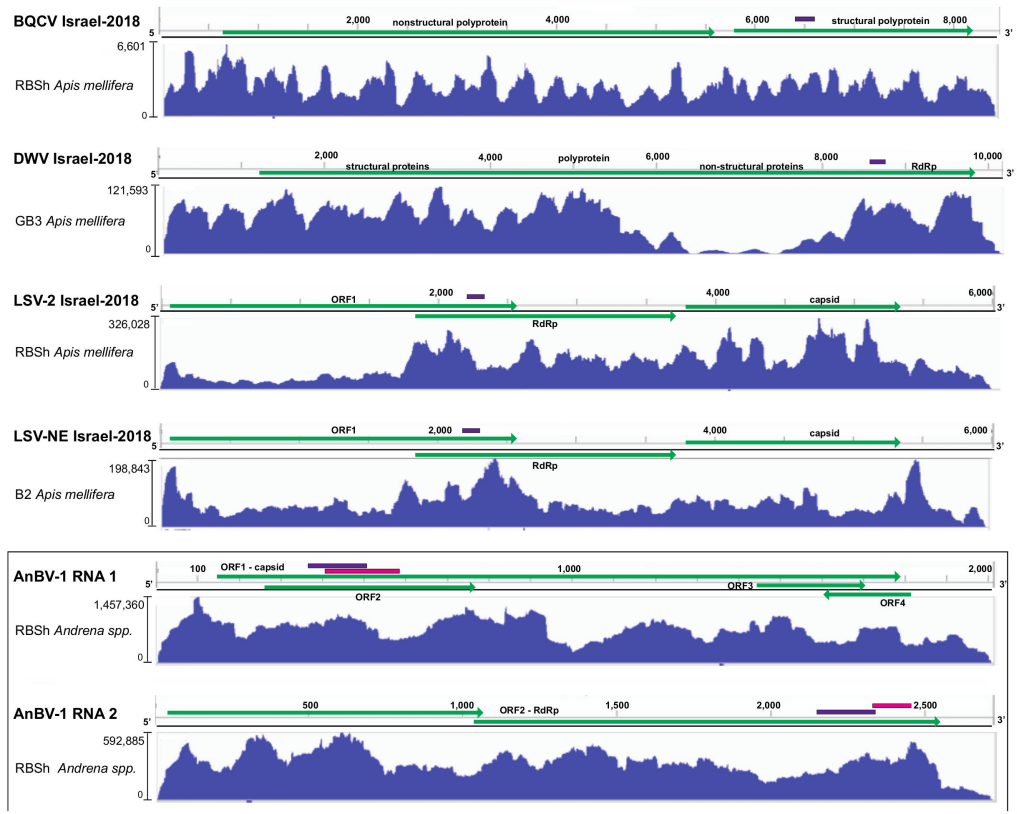

Figure 2. Sequence coverage of virus genome variants characterized by high-throughput sequencing and virus-specific qPCR. Reads in the sequence library with the highest number of reads were aligned to the consensus genome variants identified in this study including BQCV Israel-2018 (MW397638), DWV Israel-2018 (MW397639), LSV-2 Israel-2018 (MW397637), and LSV-NE Israel-2018 (MW397636), and to both genome segments of Andrena-associated bee virus-1 (AnBV-1), the novel bicistronic (+) ssRNA virus identified in this study (MW397640, MW397640). Vertical and horizontal Scheme 3.2.2. Deformed wing virus.

Deformed wing virus strains commonly infect honey bees, replicate in and are transmitted by Varroa destructor mites that parasitize honey bees, and infect native and wild bee species and other insects $[52,55,65,79,80,86,88,140,141]$. Infection of developing honey bees may result in wing deformities that result in death during or shortly after emergence, whereas viral load and the ill effects of virus infection vary in adults, which can harbor between $1 \times 10^{5}$ to $\geq 5 \times 10^{12}$ viral RNA copies per bee (estimated from qPCR values $\geq 2 \times 10^{9}$ copes $/ 100 \mathrm{ng}$ RNA and a total RNA per bee $\sim 50 \mathrm{mg}$ ) $[61,89,91,142-144]$. Deformed wing virus infections have been associated with small colony population size and overwinter losses $[89,95,145]$, and DWV infections coupled with high infestation of Varroa destructor mites, which also vector DWV, can kill colonies [69,78,146-148].

The DWV strains described in the literature include DWV-A, DWV-B (also called VDV1 ), and DWV-C, as well as recombinant viruses $[127,144,149,150]$. DWV-A and DWV-B share approximately $84 \%$ nucleotide identity [70], and DWV-A/B recombinants are the most predominantly reported in literature in the US, Israel, and Europe (reviewed in $[42,45,146]$ ). Experimental evidence indicates that pupae infected with either DWV-A or DWV-B, and recombinant DWV-A/B viruses, can develop deformed wing pathology $[144,151,152]$. The deformed wing virus consensus sequence obtained in this study, DWV Israel-2018 (MW397639), is 97.3\% identical to a recombinant DWV sequence (HM067438), which 
was originally described as having $5^{\prime}$ and $3^{\prime}$ untranslated regions (UTRs) that are more similar to DWV-A, and a central protein encoding region more similar to DWV-B $[127,144]$ (Supplementary Figures S2 and S3 and Table S4). Although DWV Israel-2018 and DWVHM067438 share $97.3 \%$ nucleotide identity across most of the genome, they are divergent in a small region within the $5^{\prime}$ end of the polyprotein coding sequence (i.e., nucleotides 1160-1540). In this small region, DWV Israel-2018 best aligns to DWV-A (NC_004830; Supplementary Figure S3). DWV Israel-2018 is similar to DWV-B strains in that it has an $11 \mathrm{nt}$ gap when aligned with DWV-A strains (Supplementary Figure S3). Together, this and other studies indicate that recombinant strains are prevalent and abundant. Overall, the extent of DWV variability and abundance may be under appreciated since most studies quantify viruses using primers that amplify short products from conserved regions of the genome, including the RNA-dependent RNA polymerase encoding region (Figure 2). The depth of sequence coverage was highest in the Apis mellifera library generated from the Galon3 site (GB3) which was dominated by white mustard (Sinapis alba), but had low honey bee activity on the sample date (Figure 2). The depth of sequence coverage was very high over most of the genome (i.e., up to $121,593 \times$ coverage).

\subsubsection{Lake Sinai virus}

Lake Sinai virus-1 (LSV-1) and Lake Sinai virus-2 (LSV-2) were the first two viruses identified in what is now recognized as the Sinaivirus group, which includes over 200 NCBI sequence entries ranging in nucleotide identity from $~ 63 \%$ to $100 \%$ (Supplementary Table S5) [61,111,132]. LSV-1 and LSV-2, which serve as type species for this group, are $71 \%$ identical at the nucleotide level and are also distinguished by differences in their protein coding regions [61]. The LSV-1 capsid encoding region overlaps with the RdRp gene in the +1 reading frame for $125 \mathrm{nt}$ before ending in a pair of stop codons, whereas the LSV-2 capsid is in frame with the RdRp [61]. The protein coding regions of LSV-2 are separated by $18 \mathrm{nt}$, whereas other isolates, including those described from a 2015 Belgium sample cohort, contain a variable spacer (19-23 nt) between the capsid protein and the RdRp protein encoding region [153].

The majority of the unique LSV contigs in this study were most similar to LSV-2 (HQ888865). The LSV-2 contigs included the longest (up to $5997 \mathrm{nt}$ ) and most abundant contig (2.4 million estimate counts or 49,514 transcripts per million (tpm)), which accounted for $37.4 \%$ of the LSV-2 contigs that were clearly assigned to a particular NCBI designated LSV species/strain. Contigs most similar to LSV-NE (NC_035113) were also well represented in sequence libraries (i.e., accounting for $41 \%$ of easily assigned unique contigs, including a $5952 \mathrm{nt}$ in length contig with an estimated read count of 251,659).

The LSV-2 Israel-2018 consensus sequence (MW397637) identified in this study, via alignment and assembly of unique LSV-2 contigs $>400 \mathrm{nt}$, was $77 \%$ identical to LSV-2 (HQ888865) (Supplementary Figure S4 and Table S5). Interestingly, the LSV-2 Israel-2018 consensus sequence and LSV-2 HQ888865 sequence share less nucleotide identity from nucleotide position 2006 to 2156, whereas this region of LSV-1 (HQ871931) and LSV-2 (HQ888865) virus strains is identical (i.e., 2105-2231). LSV-2 Israel-2018 sequence coverage was greatest in the Apis mellifera library from the RBSh site, with up to 326,028x coverage in the middle of the genome and over 50,000x coverage at the $5^{\prime}$ and $3^{\prime}$ ends of the genome (Figure 2). The capsid and $\mathrm{RdRp}$ encoding regions of this variant were separated by 19 nucleotides.

The LSV-NE Israel-2018 consensus sequence (MW397636) is most similar to LSVNE sequence (NC_035113) with which it shares $84 \%$ nucleotide identity (Supplementary Figure S5 and Table S5). Unique contigs (>400 nt) assembled from RNAseq reads provided up to $12 \times$ contig coverage. However, it is important to note that this does not depict true sequencing depth, which is illustrated in Figure 2 with coverage of up to $198,843 \times$ in the Apis mellifera sequencing library from the Berko2 (B2) site, which had high floral diversity and low honey bee activity. LSV-NE contig 51 was the longest (5952 nt), well-represented contig (i.e., 9209 tpm and 251,659 estimated read counts (Supplementary Figure S5)). 
High-throughput sequencing of representative samples obtained from this sample cohort was essential in the development of new qPCR primers designed to detect the viral variants in this study (Supplementary Table S3). This result underscores the importance of full sequence characterization prior to the assessment of relative viral abundance in samples obtained in different parts of the world, and likely for any sample cohort due to the quasispecies nature of RNA viruses and the potential for consensus sequence drift over time in all geographic areas. High-throughput sequencing was used to characterize the virus genomes in this study, but sequencing across a larger target nucleotide range using multiple primer sets would likely be sufficient. In addition, for some studies, designing primers for more conserved areas of the genome (i.e., the RdRp encoding region) may be best, whereas other studies may require specific primer sets for particular viral strains [111,149].

\subsection{Novel Bipartite Positive-Sense RNA Virus Identified in Andrena Mining Bees}

A novel bipartite positive-sense single-stranded RNA virus, Andrena-associated bee virus-1 (AnBV-1), was discovered via high-throughput sequencing of RNA samples from mining bees. Virus discovery efforts focused on sequence data obtained from "virusaugmented" sequence libraries, which were generated from RNA isolated from nuclease treated lysates of pooled mining bee or honey bee samples. The purpose of nuclease treatment prior to RNA isolation was to digest all unprotected, non-encapsidated nucleic acid in bee lysates and thus augment the amount of nucleic acid that was protected by virus capsids in sequencing libraries. Assembly of contigs, using Trinity, from reads that did not align with the Apis mellifera genome nor with the non-viral sequences in the bee holobiome revealed two large, novel contigs that we named AnBV-1 RNA 1 (2005 nt) and RNA 2 (2721 nt) (Supplementary Figures S6 and S7) [100,134]. These contigs were the most abundant virus-like contigs in the Andrena spp. virus-augmented library. They are also unique, as nucleotide BLAST analyses of either RNA segment resulted in no significant returns. To ensure that these contigs were not the result of assembly errors, the sequences were confirmed by PCR amplification coupled with Sanger (chain termination) sequencing (Supplementary Figure S8). Attempts to bridge the two contigs using combinations of forward and reverse primers from the individual contigs failed, and thus supported assembly data indicating that the AnBV-1 genome is bipartite (Supplementary Table S3). Collectively, these data suggest that the two contigs are derived from AnBV-1, a novel bipartite positive-sense single-stranded RNA virus (MW397640, MW397641).

High-throughput sequencing coverage of AnBV-1 was greatest in the library prepared from Andrena spp. collected at the Ramat Beit Shemesh (RBSh) site, which had low floral diversity and high honey bee activity. AnBV-1 coverage reached up to $1.45 \times 10^{6}$-fold for RNA 1 and up to $5.9 \times 10^{5}$-fold for RNA 2 (Figure 2). AnBV-1 coverage was also high from RNA extracted from a virus-augmented (i.e., nuclease treated) lysate obtained from a single Andrena bee sample that was positive for AnBV-1, but not positive for several other bee viruses, as assessed by virus / sequence-specific polymerase chain reaction (PCR) (i.e., LSV-U, IAPV, CBPV, KBV, and ABPV) and quantitative PCR for SBV, BQCV, LSV, DWV, and AmFV (Supplementary Figures S9 and S10). Rapid Amplification of cDNA Ends (RACE) in conjunction with Sanger sequencing was performed to confirm the sequence of RNA termini, which notoriously difficult to sequence due to potential RNA structure and/or repetitive sequence.

AnBV-1 open reading frames (ORFs) were predicted in SnapGene Viewer and Geneious Prime (Figure 3A and Supplementary Figures S6,7). Predicted ORF sequences and their translations were queried with BLAST and PHMMER online utilities $[113,114]$. AnBV-1 RNA 1 encodes four predicted ORFs. The largest, ORF1, is $1740 \mathrm{nt}$ in length and encodes a putative 540 aa protein. Initial BLAST analyses did not identify orthologous proteins and/or motifs in ORF1, ORF3, or ORF4. However, PHMMER analyses indicated that ORF2 of RNA 1 encodes a 161 amino acid (aa) virion protein based on its similarity to a putative virion protein from spider-associated Loderio virus (NC_031748) [115]. AnBV-1 RNA 1 ORF2 shares $25.7 \%$ aa identity with Loderio virus ORF3, which is a 193 aa protein in the 
European Molecular Biology Laboratory database, and both of these proteins fall into the SP24 family (PF16504, Uniprot A0A1D9CFP5). This protein family includes SP24, which is a $24 \mathrm{kD}$ structural protein, in a family of putative virion membrane proteins of plant and insect viruses, including the honey bee-infecting chronic bee paralysis virus. Chronic bee paralysis virus (CBPV), like AnBV-1, has a bipartite genome structure [154]. The putative CBPV capsid protein is a 183 aa protein encoded by ORF3 of RNA 2 (NC_010712). The putative AnBV-1 and CBPV capsid proteins share 21.3\% aa identity. Further support of AnBV-1 RNA 1 ORF2 encoding a virion protein was obtained from an HHpred search of the Pfam database (Pfam-A v33.1) which returned the 'SP24; putative virion membrane protein of plant and insect virus' as a top match (e-value $=0.00091)$ [155].

Analysis of the two largest open reading frames of AnBV-1 RNA 2 using BLASTp indicates that ORF2 encodes the putative RNA-dependent RNA polymerase (RdRp) (Supplementary Figures S7,11). The putative 499 aa AnBV-1 RdRp sequence produces the strongest alignment with a putative Castleton Burn virus RNA-dependent RNA polymerase, (BLASTp e-value $=0$ ), which was identified by sequencing bumble bee samples (Supplementary Figure S11) [156]. The RNA-dependent RNA polymerase proteins of AnBV-1 and Castleton Burn virus are similar. However, they share only 53.3\% amino acid identity (Supplementary Figure S11).

To gain further insight into the relationship between AnBV-1 and other insect-infecting viruses, including common well-characterized honey bee viruses in the Dicistroviridae (i.e., ABPV, BQCV, IAPV, KBV), Iflaviridae (i.e., DWV-A, DWV-B/VDV-1), and Sinaiviridae (e.g., LSV-1, LSV-2, LSV-NE) families, we constructed a phylogenetic tree of viral RdRp amino acid sequences. This analysis revealed that the AnBV-1 RdRp sequence forms a wellsupported monophyletic clade with sequences from tombus-like viruses. In particular, these results indicate that, based on their RdRp sequences, AnBV-1 shares a most recent common ancestor with Castleton Burn virus (Figure 3).

Sequence and phylogenetic data indicate that AnBV-1 is a positive-sense singlestranded RNA virus (+ssRNA). Therefore, like other +ssRNA viruses, a negative-strand copy of the viral genome must be produced during viral replication, as it serves as the template for the production of viral transcripts and full-length genome segments. Strandspecific reverse-transcription (RT)-PCR was performed on RNA isolated from AnBV-1positive samples. Visualization of AnBV-1 RNA 1 and RNA 2 products from negativestrand targeting reactions indicate that AnBV-1 productively infects bees (Supplementary Figure S12).

\subsection{Andrena-associated bee virus-1 (AnBV-1) is More Prevalent in Mining Bees}

The prevalence and abundance of AnBV-1 in honey bees and mining bees, which represents a single sampling date at each of 14 sites, was assessed at the individual bee level by qPCR (Supplementary Table S6). AnBV-1 was more prevalent in mining bees. Specifically, 71 of the 148 mining bee samples analyzed were AnBV-1 positive (48\%), whereas 22 of the 143 honey bee samples analyzed were AnBV-1 positive $(15 \%)\left(X^{2}=44.057\right.$, $\mathrm{df}=1$, and ${ }^{*} p$-value $=3 \times 10^{-11}$ ) (Figure 4). Comparison of AnBV-1 RNA 1 or RNA 2 copy number in individual AnBV-1-positive bee samples indicate that AnBV-1 RNA 1 abundance was greater in mining bees compared to honey bee samples $(p=0.0279)$, whereas the difference in RNA 2 abundance was not significant, $p=0.29$ (Figure 4). Since qPCR values represent differences in RNA abundance, including both genomic and messenger RNAs (transcripts), differences in the quantities of the AnBV-1 RNA segments may be biological and/or due to differences in qPCR efficiencies (Supplementary Table S6). Together, these data indicate that AnBV-1 is more prevalent and abundant in mining bees. 


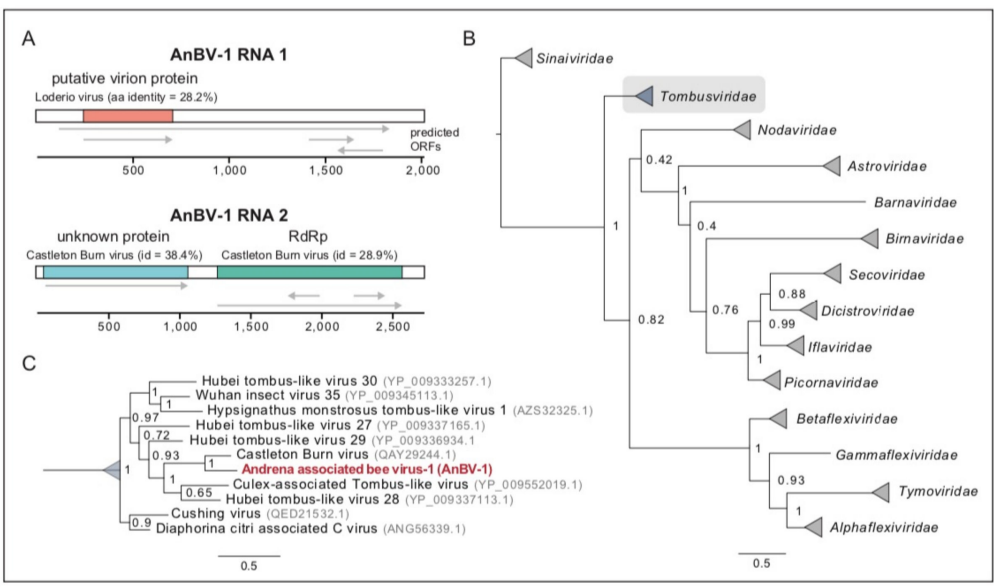

Figure 3. Andrena-associated bee virus-1 is a bipartite RNA tombus-like virus. (A). Schematic diagram of AnBV-1 genome, RNA 1 and RNA 2, with predicted open reading frames (ORFs) labeled with gene annotations based on PHMMER, HHpred and BLAST analyses and corresponding percent amino acid identity. (B). The AnBV-1 RdRp sequence forms a well-supported monophyletic clade with sequences in the Tombusviridae family (highlighted in gray). The AnBV-1 phylogenetic relationship was inferred from a maximum likelihood consensus tree of insect viruses, including previously described honey bee viruses in the Sinaiviridae, Dicistroviridae, and Iflaviridae families. Numbers on branches are Bayesian posterior probabilities (0-1); the scale bar indicates substitutions per site, and GenBank accession numbers for either the RdRp sequences or the genome sequences from where the RdRp sequence obtained are in parentheses. (C). Detailed view of the Tombusviridae clade in panel (B), illustrated that AnBV-1 RdRp is most similar to Castleton burn virus and Hubei tombus-like viruses. GenBank accessions are indicated in gray.

A

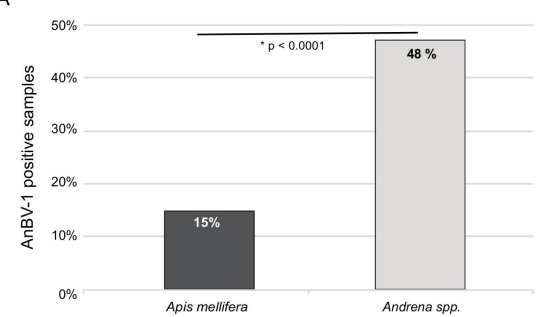

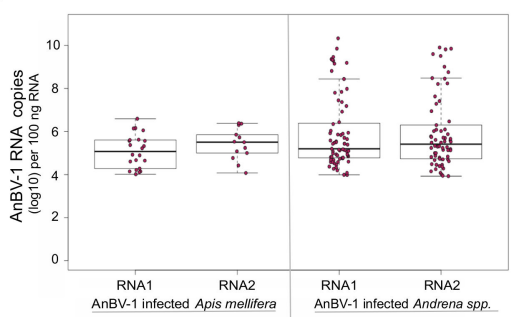

Figure 4. Andrena-associated bee virus-1 (AnBV-1) is more prevalent in Andrena. (A). AnBV-1 prevalence in this sample cohort, which represents a single sampling date at each of 14 sites, was determined from binary analysis of quantitative PCR (i.e., a sample was designated either positive (1) or negative (0) for AnBV-1) and presented as the percent AnBV-1 positive samples for each species. Specifically, 22 of the 143 Apis mellifera samples analyzed were AnBV-1 positive (15\%) and 71 of the 148 Andrena spp. samples analyzed were AnBV-1 positive (48\%). The data were analyzed using a chi square test for proportions, where $\mathrm{X}^{2}=44.057, \mathrm{df}=1$, and ${ }^{*} p$-value $=3 \times 10^{-11}$. (B). Quantitative PCR was used to determine the AnBV-1 RNA 1 or RNA 2 copy number in individual AnBV-1-positive Apis mellifera and Andrena spp. samples. Samples with undetectable AnBV-1 levels were not graphed or analyzed. Comparison of the RNA abundance between species using Dunnett's test indicates that AnBV-1 RNA 1 abundance was greater in Andrena spp. samples compared to Apis mellifera samples $(p=0.0279)$, but RNA 2 abundance between the two species was not significant, $p=0.29$.

\subsection{AnBV-1 Replicates in Primary Honey Bee Pupal Cell Cultures}

Since AnBV-1 was detected in honey bees, albeit in lower frequency and abundance, and honey bee cells support the replication of other bee-infecting viruses including SBV, IAPV, DWV, and BQCV [157-159], we examined the ability of AnBV-1 to infect and replicate in primary honey bee pupal cells maintained in culture. The inoculum for infection 
studies was clarified lysate obtained from a single Andrena sample with high AnBV-1 abundance $\left(1.3-2.6 \times 10^{8}\right.$ copies AnBV-1 per $\mu$ l lysate). Mock infections were carried out with clarified lysate obtained from a separate individual Andrena sample without detectable levels of AnBV-1 (Figure 5). Samples from three independent replicates of honey bee pupal cell cultures were harvested at $0,1,2,4,5$, and 7 days post-infection (dpi) (Figure 5 and Supplementary Figure S13). Assessment of the abundance of AnBV-1 RNA 1 and RNA 2 by qPCR indicated virus replication by 4 or 5 days post-infection in three replicates (Supplementary Figure S13). The abundance of housekeeping gene Rpl8 was consistent in each AnBV-1 and mock sample in all replicates, indicating that the cells were not dying, senescing, nor differentially replicating during the course of this experiment (Supplementary Table S7). When combined, median AnBV-1 RNA 1 levels at 4 dpi $\left(3.6 \times 10^{7}+/-2.9 \times 10^{6}\right.$ copies per $24 \mathrm{ng}$ RNA $)$ were greater than at $0 \mathrm{dpi}\left(1.4 \times 10^{7}\right.$ $+/-1.5 \times 10^{6}$ copies per $24 \mathrm{ng}$ RNA) (Figure 5A, left panel, $p$-value $=0.0714$ ). Though a similar trend was observed for AnBV-1 RNA 2, the increase was not statistically significant until $7 \mathrm{dpi}\left(5 \times 10^{7}+/-2.5 \times 10^{6}\right.$ copies per $24 \mathrm{ng}$ RNA $)$ as compared to $0 \mathrm{dpi}\left(1.2 \times 10^{7}\right.$ $+/-3.4 \times 10^{6}$ copies per $24 \mathrm{ng}$ RNA) (Figure 5A, right panel, $p$-value $=0.0095$ ), which is likely a reflection of the low sample size (i.e., $n=2-6$ per time point) due to the limited availability of honey bee pupal cells for infection in the late fall in Montana, when honey bee queens cease egg laying in preparation for winter. Together the increasing trend in AnBV-1 RNA, which persisted until the conclusion of the experiments at 7 dpi, indicates that AnBV-1 replicates in honey bee pupal cells (Figure 5 and Supplementary Figure S13). To provide further evidence of AnBV-1 replication in cultured primary honey bee cells, strand-specific qPCR was carried out on select samples. Results indicate an upward trend in AnBV-1-negative strand abundance over the course of infection (Figure 5B). Levels of AnBV-1 RNA 1 and RNA 2 were approximately 2-3 fold greater at $7 \mathrm{dpi}$ as compared to $1 \mathrm{dpi}$, confirming that AnBV-1 replicates in primary honey bee pupal cells.

\subsection{Sequence Analyses Indicate Virus Transmission between Sympatric Bee Species}

Previous studies that indicated viruses were shared among sympatric bee taxa based their conclusions on the phylogenetic similarity of viral RdRp or capsid amino acid sequences, which represent only a portion of the viral genomes $[54,56,64,87,160]$. Herein, we compared nucleotide identity over entire viral genomes. Viral genome sequences with greater than $90 \%$ nucleotide identity are likely shared, as this level of variation can be easily explained by the RNA diversity generated during viral genomic replication [137]. Virus consensus sequence data from specific sites and from the virus-augmented sequencing libraries indicate that viruses are transmitted between honey bees and mining bees. However, sequence data from samples pooled by site and by bee taxa indicate the suite of viruses in sympatric honey bees and mining bees was not always shared. Sequence data indicate that AnBV-1 is transmitted between mining bees and honey bees, as the consensus sequences obtained from both site-specific and virus-augmented sequencing libraries share over 99\% nucleotide identity. Likewise, DWV virus transmission between species was supported by $92 \%$ nt sequence identity in the RbSh site and in the entire sample cohort (i.e., virus-augmented libraries shared $97 \%$ nt identity). Similarly, interspecies transmission of BQCV sequences was indicated at the RBSh site (i.e., 96\% nt identity), though the coverage was lower in the mining bee sample compared to the honey bee sample. The high degree of similarity in the Lake Sinai virus group made it difficult to assess potential transmission between bee species. Sequence data indicated that LSV-NE is transmitted between honey bees and mining bees, which shared over $97 \%$ nucleotide identity in the regions of the genome with sufficient coverage in the mining bee sample (i.e., $50 \%$ of the genome, $\mathrm{nt}$ positions 700-1600 and 2800 to 4400), whereas the potential of LSV-2 transmission could not be adequately assessed by sequence analysis alone. Together, data from this singletime point, multiple-site observational cohort study indicate that viruses are transmitted between honey bees and mining bees. Sequence analysis alone is insufficient to assess the directionality of transmission. Furthermore, it is likely that for many bee-infecting 
viruses, interspecific virus transmission is multidirectional (i.e., viruses are transmitted among several bee and other insect species), and influenced by additional parameters including parasitic vectors, co-infection status, species density, habitat quality, and sample date. Therefore, studies that longitudinally monitor the prevalence and abundance in the context of numerous other factors that may impact virus transmission are required in order to better understand bee virus ecology.

A
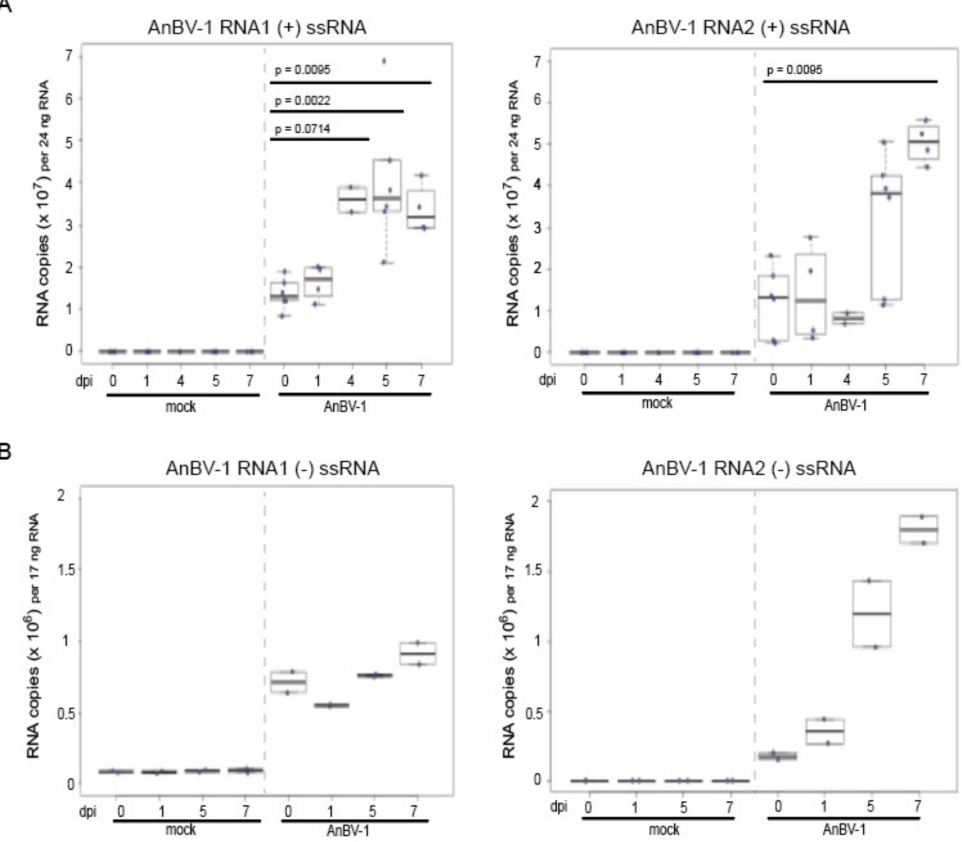

Figure 5. AnBV-1 replicates in honey bee pupal cells. To examine the ability of AnBV-1 to replicate in primary honey bee cells, cultures of pupal cells were incubated with AnBV-1-negative lysate (mock) or AnBV-1-positive lysate (AnBV-1). Total RNA was isolated from each cell culture well at 0 , $1,4,5$, or 7 days post-infection (dpi) and virus replication was assessed via strand-specific reverse transcription followed by qPCR. (A). Quantification of positive-strand, including both genome copies and transcripts, of AnBV-1 RNA 1 and AnBV-1 RNA 2 at each designated dpi. For RNA 1, $3.6 \times 10^{7}$ $+/-2.9 \times 10^{6}$ copies per $24 \mathrm{ng}$ RNA at 4 dpi vs. $1.4 \times 10^{7}+/-1.5 \times 10^{6}$ copies per $24 \mathrm{ng}$ RNA at 0 dpi. For RNA 2, $5 \times 10^{7}+/-2.5 \times 10^{6}$ copies per $24 \mathrm{ng}$ at 7 dpi vs. $1.2 \times 10^{7}+/-3.4 \times 10^{6}$ copies per 24 ng RNA at 0 dpi. (B). Quantitative assessment of negative-strand, replicative intermediate forms of AnBV-1 genome segments at each designated dpi; AnBV-1 RNA 1 and AnBV-1 RNA 2. Data were analyzed using R Studio and $p$-values were calculated using a pairwise Wilcoxon Rank Sums test with no multiple comparisons correction, and sample sizes per time point ranged from 2 to 6 samples. Relative quantity of the housekeeping gene Amrpls was consistent across all samples at all time points.

\subsection{The Probability of AnBV-1 Infection in Honey Bees Is Modulated by the Floral Community}

Since interspecies virus transmission may occur between sympatric bee species foraging on shared floral resources, we investigated patterns of virus spread in honey bee and mining bee populations in the context of the floral community and infected mining bee density in the habitat. The field data were fit with statistical models of AnBV-1 prevalence in honey bees, with the following explanatory variables: (i) the density of AnBV-1-infected mining bees, (ii) the species diversity of flowers utilized by honey bees, and (iii) the abundance of flowers of plant species visited by both mining bees and honey bees. In this study, honey bees, which are generalist pollinators, visited more flower species than the mining bees, which preferred to forage on yellow mustards (i.e., Brassicaceous plants) (Supplementary Figure S14). In the best fit model, AnBV-1 infection prevalence in honey bees was most strongly associated with low floral diversity $(p<0.0001)$ (Figure 6B). 
Indeed, AnBV-1 infections in honey bees were detected in sites with low floral diversity and were absent in honey bees in high floral diversity sites (Figure 6C and Supplementary Table S6). These results suggest a strong effect of epidemiological dilution by flower species diversity [161-164]; in sites with high floral diversity, the generalist honey bees can forage on a wide range of floral species, and therefore their exposure to flowers that are visited by mining bees, which primarily forage on yellow mustard plants, is reduced. The correlation between low flower diversity and AnBV-1 infection in honey bees can also be explained by other, non-mutually-exclusive mechanisms. For example, honey bees foraging in sites with high floral diversity may benefit from higher quality nutritional resources, which may increase their resilience against virus infections [141,165-167].

The density of AnBV-1-infected mining bees alone did not have a consistent effect on AnBV-1 infection prevalence in honey bees $(p=0.1496)$ (Figure 6B). However, its effect varied in magnitude, depending on the abundance of shared floral species between mining bees and honey bees (interaction $p=0.0038$ ) (Figure 6C). This suggests, epidemiological dilution by flower abundance. Since flowers can serve as virus transmission hubs [161], the number of AnBV-1 contaminated flowers can be diluted by many non-contaminated flowers, reducing the probability of sharing the same individual flowers between an infected mining bee and an uninfected honey bee. At very high densities of AnBV-1-infected mining bees, the impact of shared flower abundance in sites with low floral diversity appears to reverse (Figure 6B, red lines), perhaps because of honey bee recruitment to dominant floral resources [168]. In habitats with low floral diversity and a low abundance of flowers (e.g., Luzit) that are shared with mining bees, AnBV-1 infection in honey bees can occur even in the absence of detected AnBV-1 infection in mining bees (Figure 6B). The observation that AnBV-1 infections were detected only in honey bees at the Luzit site, which had low floral diversity and high honey bee activity, indicates that AnBV-1 may also spread between co-foraging honey bees (Supplementary Table S6). Whereas the relationships observed here are consistent with those expected under interspecific transmission through shared flowers, and similar to reported results from other studies that followed the temporal dynamics of different pollinator pathogen infections [161], our field data were obtained on a single sample date, and it is likely that AnBV-1 infection prevalence in honey bees, mining bees, and other bees and insects not screened in our study varies with time. Therefore, prevalence at a particular sampling date represents the status of the system on a particular sampling date (or point in time).
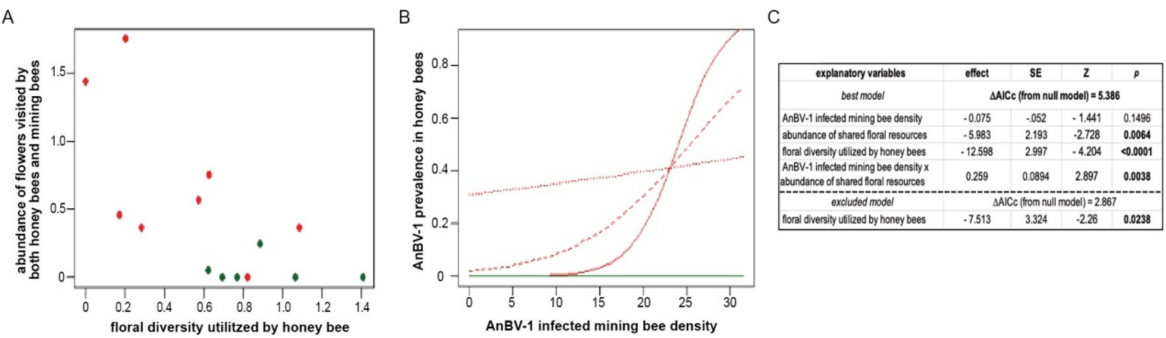

Figure 6. The probability of AnBV-1 infection in honey bees is greater in habitats with low floral diversity. (A). Patterns of bee resource use in high floral diversity sites (green) and low floral diversity sites (red), including the diversity of floral resources utilized by honey bees (horizontal axis) and the abundance of flower species that were shared between honey bees and mining bees (vertical axis); values scaled by $10,000^{-1}$ floral units. (B). Best statistical model for the roles of AnBV-1-infected mining bees and floral diversity on the probability of AnBV-1 infection in honey bees. All models are logistic generalized linear mixed models (GLMMs) for the probability of AnBV-1 presence in honey bees, with 143 observations. Scheme 2 . The best model was contrasted with a null model containing only the random effect of site. (C). Best model fit to data, describing the relationship between AnBV-1 prevalence in honey bees (vertical axis) and three habitat characteristics: (i) the density of AnBV-1-infected mining bees, (ii) the diversity of floral resources utilized by honey bees 
(red curves $=$ mean of low diversity sites, green curves $=$ mean of high diversity sites), and (iii) the abundance of flower species that are shared between honey bees and mining bees (solid = maximal abundance observed in the habitat type, dotted = minimal abundance observed in the habitat type, dashed = mean abundance observed in the habitat type). For high-diversity habitats (in green), the three curves for different floral abundances overlap.

\section{Conclusions}

In summary, data from this sample cohort underscore the importance of a broad investigation of the bee-associated virome and provide a framework for future investigation of bee virus ecology. The majority of bee-infecting viruses are RNA viruses, which often exist as quasispecies. Therefore, it is important to incorporate sequencing (e.g., highthroughput sequencing and/or targeted PCR with multiple primer sets per virus coupled with Sanger sequencing) to identify novel viruses and viral variants, prior to assessing viral prevalence and abundance at the individual bee, colony, and community levels. Virus discovery efforts have primarily focused on honey bees, but it is clear from this and other studies that the diversity of bee-infecting viruses is greater than currently appreciated. Likewise, detection of bee-infecting viruses, which are typically referred to as "honey beeinfecting viruses", in a broad range of hymenopteran insects, indicates that investigation of interspecific virus transmission should consider a broader potential host range.

For this study, we opted to sample multiple sites, with distinct floral and bee communities, within a single blooming season and focus our analyses on the two most prevalent co-foraging bee taxa (i.e., Apis mellifera and four specialist Andrena spp.) and a novel bipartite +ssRNA virus named Andrena-associated bee virus-1 (AnBV-1) that replicates in mining bees, honey bees, and primary honey bee pupal cell culture. AnBV-1 was most prevalent and abundant in mining bees, though it was also detected in honey bees, albeit at lower frequency. Statistical modeling that examined the roles of ecological factors, including floral diversity and infected mining bee density, indicated that the probability of AnBV-1 infection in honey bees is greater in low-floral-diversity habitats, and suggested that interspecific transmission is strongly modulated by the floral community in the habitat. Future studies that examine the temporal dynamics of bee/insect density, virus prevalence and abundance, and habitat-associated parameters will be important to reveal patterns of virus transmission, clearance, and reinfection of bee taxa within bee communities. Likewise, studies aimed at understanding the impact of AnBV-1 on individual bees, bee colonies, and bee communities are required. It will also be interesting to investigate the impact of multiple viruses (individually and in the context of other co-infections) from the individual bee to community levels to determine their impact on bee behavior and pollination activity, and/or survival. The data from this study suggest effects of epidemiological dilution by floral diversity and abundance, and that interspecific virus transmission is modulated by the floral community in the habitat. Therefore, land management strategies that aim to enhance floral diversity and abundance may reduce AnBV-1 (and possibly other viruses) spread between co-foraging bees. Regardless of the impact of the bee/insect community virome, efforts aimed at enhancing and/or maintaining bee forage in managed and wild landscapes will likely benefit all plant and animal communities.

Supplementary Materials: The following are available online at https:/ / www.mdpi.com/1999-491 5/13/2/291/s1. Excel file with Supplementary Tables S1-S10, and combined pdf document with Supplementary Figures S1-S14. Supplementary Figure titles listed below for review: Supplementary Table S1. Sample site description. Supplementary Table S2. Summary of samples analyzed by high-throughput (RNAseq) sequencing and data summary. Supplementary Table S3. Primers used in this study. Supplementary Table S4. Percent nucleotide identity of select deformed wing virus (DWV) genomes. Supplementary Table S5. Percent nucleotide identity of select Lake Sinai virus genomes. Supplementary Table S6. Abundance of Andrena-associated bee virus-1 (AnBV-1) in individual bee samples. Supplementary Table S7. Positive and negative strand analysis of AnBV-1 RNA 1 and RNA 2 abundance in individual wells of honey bee pupal cells. Supplementary Table S8. Virus analysis in individual bee samples utilized as AnBV-1 inocula to infect primary honey bee 
pupal cells. Supplementary Table S9. Virus sequence source and NCBI identification numbers. Supplementary Table S10. Sequences downloaded from Schoonvaere et al. 2018 publication. Supplementary Figure S1. Black queen cell virus Israel-2018 nucleotide alignment with BQCV reference sequence. Supplementary Figure S2. Virus nucleotide alignments between reference sequence and DWV variant from Israel-2018. Supplementary Figure S3. Virus nucleotide alignments between reference sequences and DWV variant from Israel-2018. Supplementary Figure S4. Lake Sinai virus 2 Israel-2018 nucleotide alignment with LSV-2 reference sequence. Supplementary Figure S5. Lake Sinai virus NE Israel-2018 nucleotide alignment with LSV-NE Reference Sequence. Supplementary Figure S6. Andrena-associated bee virus-1 (AnBV-1) RNA 1. Supplementary Figure S7. Andrenaassociated bee virus-1 (AnBV-1) RNA 2. Supplementary Figure S8. Sanger sequencing confirmation of AnBV-1 RNA 1 and AnBV-1 RNA 2 sequences. Supplementary Figure S9. Assessment of virus presence in Individual Andrena spp. lysates confirms absence of LSVs, IAPV, CBPV, KBV, and ABPV. Supplementary Figure S10. Andrena-associated bee virus-1 (AnBV-1) RNA 1 and RNA 2 RNAseq coverage from virus-augmented sequencing library. Supplementary Figure S11. Andrena-associated bee virus 1 (AnBV-1) RNA 2-RdRp. Supplementary Figure S12. AnBV-1 RNA 1 and RNA 2 negative strand detection. Supplementary Figure S13. AnBV-1 replicates in honey bee pupal cells—three independent replicates. Supplementary Figure S14. Visits distribution of Apis mellifera and Andrena spp. by flower species.

Author Contributions: Conceptualization, M.L.F., Y.M., A.S. and N.C.; methodology, M.L.F., C.C.C., Y.M., N.C., A.S., I.K., N.A., K.F.D., A.J.M., T.E. and N.A.; validation, K.F.D., C.C.C., M.L.F., I.K., A.S. and Y.M.; formal analysis, M.L.F., K.F.D., A.J.M., C.C.C., T.W., I.K., A.S and Y.M., investigation, M.L.F., K.F.D., A.J.M., C.C.C., I.K., N.A., T.E., A.S., B.R. and Y.M.; resources, Y.M., M.L.F., A.S. and N.C.; data curation, C.C.C., K.F.D. and M.L.F.; writing—original draft preparation, M.L.F., K.F.D., A.J.M., T.W., Y.M., A.S. and I.K.; writing-review and editing, M.L.F., C.C.C., K.F.D., A.J.M., B.W., T.W., N.C., A.S., Y.M., I.K. and B.R.; visualization, M.L.F., K.F.D., A.J.M., T.W., C.C.C., I.K. and A.S., supervision, M.L.F., Y.M., A.S. and N.C.; project administration, Y.M., M.L.F., and A.S.; funding acquisition, Y.M., M.L.F., A.S. and N.C. All authors have read and agreed to the published version of this manuscript.

Funding: The research described herein was funded by the United States-Israel Binational Science Foundation (BSF) (award number 2016383). Funding was awarded to Y.M., M.L.F., A.S., and N.C. In addition, A.J.M. is partially funded by the Project Apis m.-Costco Scholar Fellowship and M.L.F. is supported by the National Science Foundation CAREER Program (award number 1651561). The funders had no role in study design, data collection and analysis, decision to publish, or preparation of this manuscript.

Institutional Review Board Statement: Not applicable.

Informed Consent Statement: Not applicable.

Data Availability Statement: The majority of the data generated or analyzed during this study are included in this published article and its Supplementary Materials files (available online). Additional data are available from the corresponding author upon request, and sequence data are available on GenBank and the NCBI Sequence Read Archive (BioProject ID PRJNA687318). Custom bash and R scripts: https://github.com/charlieccarey/viral_transcriptome_of_bees.

Acknowledgments: We are grateful to Achik Dorchin and Gideon Pisanty, the Steinhardt Museum of Natural History, Tel-Aviv University, for help in the field and for identification of collected mining bee species. We thank Flenniken Lab members (Fenali Parekh and Naomi Kaku) for reviewing this manuscript prior to submission.

Conflicts of Interest: The authors declare no conflict of interest.

\section{References}

1. Ollerton, J.; Winfree, R.; Tarrant, S. How many flowering plants are pollinated by animals? Oikos 2011, 120, 321-326. [CrossRef]

2. Gallai, N.; Salles, J.-M.; Settele, J.; Vaissière, B.E. Economic valuation of the vulnerability of world agriculture confronted with pollinator decline. Ecol. Econ. 2009, 68, 810-821. [CrossRef]

3. Michener, C.D. The Bees of the World, 2nd ed.; John Hopkins University Press: Baltimore, MD, USA; London, UK, 2007.

4. Cariveau, D.P.; Nayak, G.K.; Bartomeus, I.; Zientek, J.; Ascher, J.S.; Gibbs, J.; Winfree, R. The Allometry of Bee Proboscis Length and Its Uses in Ecology. PLoS ONE 2016, 11, e0151482. [CrossRef] 
5. Kimoto, C.; Debano, S.J.; Thorp, R.W.; Rao, S.; Stephen, W.P. Investigating temporal patterns of a native bee community in a remnant North American bunchgrass prairie using blue vane traps. J. Insect Sci. 2012, 12, 108. [CrossRef]

6. Gathmann, A.; Tscharntke, T. Foraging ranges of solitary bees. J. Anim. Ecol. 2002, 71, 757-764. [CrossRef]

7. Wagner, D.L. Insect Declines in the Anthropocene. Annu. Rev. Entomol. 2020, 65, 457-480. [CrossRef]

8. Van Klink, R.; Bowler, D.E.; Gongalsky, K.B.; Swengel, A.B.; Gentile, A.; Chase, J.M. Meta-analysis reveals declines in terrestrial but increases in freshwater insect abundances. Science 2020, 368, 417. [CrossRef]

9. Duchenne, F.; Thebault, E.; Michez, D.; Gerard, M.; Devaux, C.; Rasmont, P.; Vereecken, N.J.; Fontaine, C. Long-term effects of global change on occupancy and flight period of wild bees in Belgium. Glob. Chang. Biol. 2020, 26, 6753-6766. [CrossRef]

10. Goulson, D.; Nicholls, E.; Botias, C.; Rotheray, E.L. Bee declines driven by combined stress from parasites, pesticides, and lack of flowers. Science 2015, 347, 1255957. [CrossRef]

11. Mathiasson, M.; Rehan, S. Status changes in the wild bees of north-eastern North America over 125 years revealed through museum specimens. Insect Conserv. Divers. 2019, 12, 278-288. [CrossRef]

12. Goulson, D.; Lye, G.C.; Darvill, B. Decline and Conservation of Bumble Bees. Annu. Rev. Entomol. 2008, 53, 191-208. [CrossRef]

13. Cameron, S.A.; Lozier, J.D.; Strange, J.P.; Koch, J.B.; Cordes, N.; Solter, L.F.; Griswold, T.L. Patterns of widespread decline in North American bumble bees. Proc. Natl. Acad. Sci. USA 2011, 108, 662-667. [CrossRef]

14. Arbetman, M.P.; Gleiser, G.; Morales, C.L.; Williams, P.; Aizen, M.A. Global decline of bumblebees is phylogenetically structured and inversely related to species range size and pathogen incidence. Proc. R. Soc. B Biol. Sci. 2017, 284, 20170204. [CrossRef]

15. Aizen, M.A.; Harder, L.D. The Global Stock of Domesticated Honey Bees Is Growing Slower Than Agricultural Demand for Pollination. Curr. Biol. 2009, 19, 915-918. [CrossRef]

16. van Engelsdorp, D.; Meixner, M.D. A historical review of managed honey bee populations in Europe and the United States and the factors that may affect them. J. Invertebr. Pathol. 2010, 103, S80-S95. [CrossRef] [PubMed]

17. Russo, L. Positive and Negative Impacts of Non-Native Bee Species around the World. Insects 2016, 7, 69. [CrossRef]

18. Stork, N.E. How Many Species of Insects and Other Terrestrial Arthropods Are There on Earth? Annu. Rev. Entomol. 2018, 63, 31-45. [CrossRef]

19. Langstroth, L. Langstroth on the Hive and the Honey Bee; Xist Publishing: Rosenberg, TX, USA, 2014.

20. Beekman, M.; Ratnieks, F.L.W. Long-Range Foraging by the Honey-Bee, Apis mellifera L. Funct. Ecol. 2000, 14, 490-496. [CrossRef]

21. Visscher, P.K.; Seeley, T.D. Foraging Strategy of Honeybee Colonies in a Temperate Deciduous Forest. Ecology 1982, 63, $1790-1801$. [CrossRef]

22. Couvillon, M.J.; Pearce, F.C.R.; Accleton, C.; Fensome, K.A.; Quah, S.K.L.; Taylor, E.L.; Ratnieks, F.L.W. Honey bee foraging distance depends on month and forage type. Apidologie 2015, 46, 61-70. [CrossRef]

23. Soroker, V.; Hetzroni, A.; Yakobson, B.; David, D.; David, A.; Voet, H.; Slabezki, Y.; Efrat, H.; Levski, S.; Kamer, Y.; et al. Evaluation of colony losses in Israel in relation to the incidence of pathogens and pests. Apidologie 2011, 42. [CrossRef]

24. Lee, K.V.; Steinhauer, N.; Rennich, K.; Wilson, M.E.; Tarpy, D.R.; Caron, D.M.; Rose, R.; Delaplane, K.S.; Baylis, K.; Lengerich, E.J.; et al. A national survey of managed honey bee 2013-2014 annual colony losses in the USA. Apidologie 2015, 46, 292-305. [CrossRef]

25. Spleen, A.M.; Lengerich, E.J.; Rennich, K.; Caron, D.; Rose, R.; Pettis, J.S.; Henson, M.; Wilkes, J.T.; Wilson, M.; Stitzinger, J.; et al. A national survey of managed honey bee 2011-2012 winter colony losses in the United States: Results from the Bee Informed Partnership. J. Apic. Res. 2015, 52, 44-53. [CrossRef]

26. Steinhauer, N.; van Engelsdorp, D. Using Epidemiological Methods to Improve Honey Bee Colony Health. In Beekeeping-From Science to Practice; Springer International Publishing: Cham, Switzerland, 2017; Volume 19, pp. 125-142.

27. Steinhauer, N.A.; Rennich, K.; Wilson, M.E.; Caron, D.M.; Lengerich, E.J.; Pettis, J.S.; Rose, R.; Skinner, J.A.; Tarpy, D.R.; Wilkes, J.T.; et al. A national survey of managed honey bee 2012-2013 annual colony losses in the USA: Results from the Bee Informed Partnership. J. Apic. Res. 2015, 53, 1-18. [CrossRef]

28. Traynor, K.S.; Rennich, K.; Forsgren, E.; Rose, R.; Pettis, J.; Kunkel, G.; Madella, S.; Evans, J.; Lopez, D.; vanEngelsdorp, D. Multiyear survey targeting disease incidence in US honey bees. Apidologie 2016, 47, 325-347. [CrossRef]

29. van Engelsdorp, D.; Caron, D.; Hayes, J.; Underwood, R.; Henson, M.; Rennich, K.; Spleen, A.; Andree, M.; Snyder, R.; Lee, K.; et al. A national survey of managed honey bee 2010-11 winter colony losses in the USA: Results from the Bee Informed Partnership. J. Apic. Res. 2015, 51, 115-124. [CrossRef]

30. van Engelsdorp, D.; Hayes, J.; Underwood, R.M.; Pettis, J. A Survey of Honey Bee Colony Losses in the U.S. Fall 2007 to Spring 2008. PLOS ONE 2008, 3, e4071.

31. Bruckner, S.; Steinhauer, N.; Aurell, S.D.; Caron, D.M.; Ellis, J.D.; Fauvel, A.M.; Kulhanek, K.; McArt, S.; Mullen, E.; Rangel, J.; et al. 2018-2019 Honey Bee Colony Losses in the United States: Preliminary Results; The Bee Informed Partnership: Bethesda, MD, USA, 2020.

32. Seitz, N.; Traynor, K.S.; Steinhauer, N.; Rennich, K.; Wilson, M.E.; Ellis, J.D.; Rose, R.; Tarpy, D.R.; Sagili, R.R.; Caron, D.M.; et al. A national survey of managed honey bee 2014-2015 annual colony losses in the USA. J. Apic. Res. 2015, 54, 292-304. [CrossRef]

33. Kulhanek, K.; Steinhauer, N.; Rennich, K.; Caron, D.M.; Sagili, R.R.; Pettis, J.S.; Ellis, J.D.; Wilson, M.E.; Wilkes, J.T.; Tarpy, D.R.; et al. A national survey of managed honey bee 2015-2016 annual colony losses in the USA. J. Apic. Res. 2017, 56, 328-340. [CrossRef] 
34. Ascher, J.S. Pickering Discover Life Bee Species Guide and World Checklist (Hymenoptera: Apoidea: Anthophila). Available online: http:/ / www.discoverlife.org/mp/20q?guide=Apoidea_species (accessed on 12 January 2020).

35. Pisanty, G.; Richter, R.; Martin, T.; Dettman, J.; Cardinal, S. Molecular phylogeny and historical biogeography of andrenine bees (Hymenoptera: Andrenidae). bioRxiv 2020. [CrossRef]

36. Paxton, R.J.; Thoren, P.A.; Tengo, J.; Estoup, A.; Pamilo, P. Mating structure and nestmate relatedness in a communal bee, Andrena jacobi (Hymenoptera, Andrenidae), using microsatellites. Mol. Ecol. 1996, 5, 511-519. [CrossRef]

37. Michener, C.D. The Social Behavior of the Bees: A Comparative Study; Belknap Pr.: Cambridge, MA, USA, 1974.

38. Wood, T.J.; Roberts, S.P.M. An assessment of historical and contemporary diet breadth in polylectic Andrena bee species. Biol. Conserv. 2017, 215, 72-80. [CrossRef]

39. Larkin, L.L.; Neff, J.L.; Simpson, B.B. The evolution of a pollen diet: Host choice and diet breadth of Andrena bees (Hymenoptera: Andrenidae). Apidologie 2008, 39, 133-145. [CrossRef]

40. Cornman, R.S.; Tarpy, D.R.; Chen, Y.; Jeffreys, L.; Lopez, D.; Pettis, J.S.; vanEngelsdorp, D.; Evans, J.D. Pathogen Webs in Collapsing Honey Bee Colonies. PLoS ONE 2012, 7, e43562. [CrossRef]

41. Brutscher, L.M.; McMenamin, A.J.; Flenniken, M.L. The Buzz about Honey Bee Viruses. PLoS Pathog. 2016, 12 , e1005757. [CrossRef]

42. Grozinger, C.M.; Flenniken, M.L. Bee Viruses: Ecology, Pathogenicity, and Impacts. Annu. Rev. Entomol. 2019, 64, 205-226. [CrossRef]

43. McMenamin, A.J.; Flenniken, M.L. Recently identified bee viruses and their impact on bee pollinators. Curr. Opin. Insect Sci. 2018, 26, 120-129. [CrossRef] [PubMed]

44. Ryabov, E.V. Invertebrate RNA virus diversity from a taxonomic point of view. J. Invertebr. Pathol. 2017, 147, 37-50. [CrossRef] [PubMed]

45. Beaurepaire, A.; Piot, N.; Doublet, V.; Antunez, K.; Campbell, E.; Chantawannakul, P.; Chejanovsky, N.; Gajda, A.; Heerman, M.; Panziera, D.; et al. Diversity and Global Distribution of Viruses of the Western Honey Bee, Apis mellifera. Insects 2020, 11, 239. [CrossRef]

46. Gauthier, L.; Cornman, S.; Hartmann, U.; Cousserans, F.; Evans, J.; de Miranda, J.; Neumann, P. The Apis mellifera Filamentous Virus Genome. Viruses 2015, 7, 3798-3815. [CrossRef] [PubMed]

47. Hou, C.; Li, B.; Deng, S.; Chu, Y.; Diao, Q. Diagnosis and distribution of the Apis mellifera filamentous virus (AmFV) in honey bees (Apis mellifera) in China. Insectes Soc. 2017, 64, 597-603. [CrossRef]

48. Galbraith, D.A.; Fuller, Z.; Brockmann, A.; Frazier, M.; Gikungu, M.W.; Kapheim, K.M.; Kerby, J.T.; Kocher, S.D.; Losyev, O.; Muli, E.; et al. Investigating the viral ecology of global bee communities with high-throughput metagenomics. Sci. Rep. 2018, 8, 1-11. [CrossRef] [PubMed]

49. Schoonvaere, K.; Smagghe, G.; Francis, F.; de Graaf, D.C. Study of the Metatranscriptome of Eight Social and Solitary Wild Bee Species Reveals Novel Viruses and Bee Parasites. Front. Microbiol. 2018, 9, 177. [CrossRef]

50. Ravoet, J.; De Smet, L.; Meeus, I.; Smagghe, G.; Wenseleers, T.; de Graaf, D.C. Widespread occurrence of honey bee pathogens in solitary bees. J. Invertebr. Pathol. 2014, 122, 55-58. [CrossRef] [PubMed]

51. Dolezal, A.G.; Hendrix, S.D.; Scavo, N.A.; Carrillo-Tripp, J.; Harris, M.A.; Wheelock, M.J.; O’Neal, M.E.; Toth, A.L. Honey Bee Viruses in Wild Bees: Viral Prevalence, Loads, and Experimental Inoculation. PLoS ONE 2016, 11, e0166190. [CrossRef] [PubMed]

52. Alger, S.A.; Burnham, P.A.; Boncristiani, H.F.; Brody, A.K. RNA virus spillover from managed honeybees (Apis mellifera) to wild bumblebees (Bombus spp.). PLoS ONE 2019, 14, e0217822. [CrossRef]

53. Alger, S.A.; Burnham, P.A.; Brody, A.K. Flowers as viral hot spots: Honey bees (Apis mellifera) unevenly deposit viruses across plant species. PLoS ONE 2019, 14, e0221800. [CrossRef]

54. Tehel, A.; Brown, M.J.; Paxton, R.J. Impact of managed honey bee viruses on wild bees. Curr. Opin. Virol. 2016, 19, 16-22. [CrossRef]

55. Zhang, X.; He, S.Y.; Evans, J.D.; Pettis, J.S.; Yin, G.F.; Chen, Y.P. New evidence that deformed wing virus and black queen cell virus are multi-host pathogens. J. Invertebr. Pathol. 2012, 109, 156-159. [CrossRef] [PubMed]

56. Singh, R.; Levitt, A.L.; Rajotte, E.G.; Holmes, E.C.; Ostiguy, N.; van Engelsdorp, D.; Lipkin, W.I.; Depamphilis, C.W.; Toth, A.L.; Cox-Foster, D.L. RNA Viruses in Hymenopteran Pollinators: Evidence of Inter-Taxa Virus Transmission via Pollen and Potential Impact on Non-Apis Hymenopteran Species. PLoS ONE 2010, 5, e14357. [CrossRef]

57. Radzevičiūtè, R.; Theodorou, P.; Husemann, M.; Japoshvili, G.; Kirkitadze, G.; Zhusupbaeva, A.; Paxton, R.J. Replication of honey bee-associated RNA viruses across multiple bee species in apple orchards of Georgia, Germany and Kyrgyzstan. J. Invertebr. Pathol. 2017, 146, 14-23. [CrossRef]

58. de Miranda, J.; Cornman, R.; Evans, J.; Semberg, E.; Haddad, N.; Neumann, P.; Gauthier, L. Genome Characterization, Prevalence and Distribution of a Macula-Like Virus from Apis mellifera and Varroa destructor. Viruses 2015, 7, 3586-3602. [CrossRef]

59. Remnant, E.J.; Shi, M.; Buchmann, G.; Blacquiere, T.; Holmes, E.C.; Beekman, M.; Ashe, A. A Diverse Range of Novel RNA Viruses in Geographically Distinct Honey Bee Populations. J. Virol. 2017, 91, e00158-17. [CrossRef] [PubMed]

60. Levin, S.; Galbraith, D.; Sela, N.; Erez, T.; Grozinger, C.M.; Chejanovsky, N. Presence of Apis Rhabdovirus-1 in Populations of Pollinators and Their Parasites from Two Continents. Front. Microbiol. 2017, 8, 2482. [CrossRef] 
61. Runckel, C.; Flenniken, M.L.; Engel, J.C.; Ruby, J.G.; Ganem, D.; Andino, R.; DeRisi, J.L. Temporal analysis of the honey bee microbiome reveals four novel viruses and seasonal prevalence of known viruses, Nosema, and Crithidia. PLoS ONE 2011, 6, e20656. [CrossRef]

62. Levin, S.; Sela, N.; Chejanovsky, N. Two novel viruses associated with the Apis mellifera pathogenic mite Varroa destructor. Sci. Rep. 2016, 6, 37710. [CrossRef] [PubMed]

63. Levin, S.; Sela, N.; Erez, T.; Nestel, D.; Pettis, J.; Neumann, P.; Chejanovsky, N. New Viruses from the Ectoparasite Mite Varroa destructor Infesting Apis mellifera and Apis cerana. Viruses 2019, 11, 94. [CrossRef] [PubMed]

64. Levitt, A.L.; Singh, R.; Cox-Foster, D.L.; Rajotte, E.; Hoover, K.; Ostiguy, N.; Holmes, E.C. Cross-species transmission of honey bee viruses in associated arthropods. Virus Res. 2013, 176, 232-240. [CrossRef] [PubMed]

65. Payne, A.N.; Shepherd, T.F.; Rangel, J. The detection of honey bee (Apis mellifera)-associated viruses in ants. Sci. Rep. 2020, 10, 2923. [CrossRef]

66. Mordecai, G.J.; Brettell, L.E.; Pachori, P.; Villalobos, E.M.; Martin, S.J.; Jones, I.M.; Schroeder, D.C. Moku virus; a new Iflavirus found in wasps, honey bees and Varroa. Sci. Rep. 2016, 6, 1304. [CrossRef]

67. Chen, Y.P.; Siede, R. Honey Bee Viruses. In Advances in Clinical Chemistry; Elsevier: Amsterdam, The Netherlands, 2007; Volume 70, pp. 33-80.

68. Bowen-Walker, P.L.; Martin, S.J.; Gunn, A. The transmission of deformed wing virus between honeybees (Apis mellifera L.) by the ectoparasitic mite Varroa jacobsoni Oud. J. Invertebr. Pathol. 1999, 73, 101-106. [CrossRef]

69. Nazzi, F.; Brown, S.P.; Annoscia, D.; Del Piccolo, F.; Di Prisco, G.; Varricchio, P.; Della Vedova, G.; Cattonaro, F.; Caprio, E.; Pennacchio, F. Synergistic Parasite-Pathogen Interactions Mediated by Host Immunity Can Drive the Collapse of Honeybee Colonies. PLoS Pathog. 2012, 8, e1002735. [CrossRef]

70. Ongus, J.R. Complete sequence of a picorna-like virus of the genus Iflavirus replicating in the mite Varroa destructor. J. Gen. Virol. 2004, 85, 3747-3755. [CrossRef]

71. Wilfert, L.; Long, G.; Leggett, H.C.; Schmid-Hempel, P.; Butlin, R.; Martin, S.J.M.; Boots, M. Deformed wing virus is a recent global epidemic in honeybees driven by Varroa mites. Science 2016, 351, 594-597. [CrossRef] [PubMed]

72. Chen, Y.P.; Pettis, J.S.; Corona, M.; Chen, W.P.; Li, C.J.; Spivak, M.; Visscher, P.K.; De Grandi-Hoffman, G.; Boncristiani, H.; Zhao, Y.; et al. Israeli Acute Paralysis Virus: Epidemiology, Pathogenesis and Implications for Honey Bee Health. PLoS Pathog. 2014, 10, e1004261. [CrossRef] [PubMed]

73. Chen, Y.; Pettis, J.S.; Evans, J.D.; Kramer, M.; Fedlaufer, M. Transmission of Kashmir bee virus by the ectoparasitic mite Varroa destructor. Apidologie 2004, 35, 441-448. [CrossRef]

74. Celle, O.; Blanchard, P.; Olivier, V.; Schurr, F.; Cougoule, N.; Faucon, J.-P.; Ribière, M. Detection of Chronic bee paralysis virus (CBPV) genome and its replicative RNA form in various hosts and possible ways of spread. Virus Res. 2008, 133, 280-284. [CrossRef] [PubMed]

75. Eyer, M.; Chen, Y.P.; Schäfer, M.O.; Pettis, J.; Neumann, P. Small hive beetle, Aethina tumida, as a potential biological vector of honeybee viruses. Apidologie 2009, 40, 419-428. [CrossRef]

76. Kwadha, C.A.; Ong'amo, G.O.; Ndegwa, P.N.; Raina, S.K.; Fombong, A.T. The Biology and Control of the Greater Wax Moth, Galleria mellonella. Insects 2017, 8, 61. [CrossRef]

77. Traiyasut, P.; Mookhploy, W.; Kimura, K.; Yoshiyama, M.; Khongphinitbunjong, K.; Chantawannakul, P. First Detection of Honey Bee Viruses in Wax Moth. Chiang Mai J. Sci. 2016, 43, 695-698.

78. Di Prisco, G.; Annoscia, D.; Margiotta, M.; Ferrara, R.; Varricchio, P.; Zanni, V.; Caprio, E.; Nazzi, F.; Pennacchio, F. A mutualistic symbiosis between a parasitic mite and a pathogenic virus undermines honey bee immunity and health. Proc. Natl. Acad. Sci. USA 2016, 113, 3203-3208. [CrossRef]

79. Gisder, S.; Aumeier, P.; Genersch, E. Deformed wing virus: Replication and viral load in mites (Varroa destructor). J. Gen. Virol. 2009, 90, 463-467. [CrossRef]

80. Martin, S.J.; Brettell, L.E. Deformed Wing Virus in Honeybees and Other Insects. Annu. Rev. Virol. 2019, 6, 49-69. [CrossRef]

81. Yanez, O.; Piot, N.; Dalmon, A.; de Miranda, J.R.; Chantawannakul, P.; Panziera, D.; Amiri, E.; Smagghe, G.; Schroeder, D.; Chejanovsky, N. Bee Viruses: Routes of Infection in Hymenoptera. Front. Microbiol. 2020, 11, 943. [CrossRef]

82. McArt, S.H.; Koch, H.; Irwin, R.E.; Adler, L.S. Arranging the bouquet of disease: Floral traits and the transmission of plant and animal pathogens. Ecol. Lett. 2014, 17, 624-636. [CrossRef]

83. Koch, H.; Brown, M.J.F.; Stevenson, P.C. The role of disease in bee foraging ecology. Curr. Opin. Insect Sci. 2017, $21,60-67$. [CrossRef] [PubMed]

84. Mazzei, M.; Carrozza, M.L.; Luisi, E.; Forzan, M.; Giusti, M.; Sagona, S.; Tolari, F.; Felicioli, A. Infectivity of DWV Associated to Flower Pollen: Experimental Evidence of a Horizontal Transmission Route. PLoS ONE 2014, 9, e113448.

85. Gisder, S.; Genersch, E. Viruses of commercialized insect pollinators. J. Invertebr. Pathol. 2017, 147, 51-59. [CrossRef]

86. Tapia-González, J.M.; Morfin, N.; Macías-Macías, J.O.; De la Mora, A.; Tapia-Rivera, J.C.; Ayala, R.; Contreras-Escareño, F.; Gashout, H.A.; Guzman-Novoa, E. Evidence of presence and replication of honey bee viruses among wild bee pollinators in subtropical environments. J. Invertebr. Pathol. 2019, 168, 107256. [CrossRef]

87. Fürst, M.A.; McMahon, D.P.; Osborne, J.L.; Paxton, R.J.; Brown, M.J.F. Disease associations between honeybees and bumblebees as a threat to wild pollinators. Nature 2014, 506, 364-366. [CrossRef] 
88. Gusachenko, O.N.; Woodford, L.; Balbirnie-Cumming, K.; Ryabov, E.V.; Evans, D.J. Evidence for and against deformed wing virus spillover from honey bees to bumble bees: A reverse genetic analysis. Sci. Rep. 2020, 10, 16847. [CrossRef] [PubMed]

89. Glenny, W.; Cavigli, I.; Daughenbaugh, K.F.; Radford, R.; Kegley, S.E.; Flenniken, M.L. Honey bee (Apis mellifera) colony health and pathogen composition in migratory beekeeping operations involved in California almond pollination. PLoS ONE 2017, 12, e0182814. [CrossRef]

90. Cavigli, I.; Daughenbaugh, K.F.; Martin, M.; Lerch, M.; Banner, K.; Garcia, E.; Brutscher, L.M.; Flenniken, M.L. Pathogen prevalence and abundance in honey bee colonies involved in almond pollination. Apidologie 2016, 47, 251-266. [CrossRef]

91. Faurot-Daniels, C.; Glenny, W.; Daughenbaugh, K.F.; McMenamin, A.J.; Burkle, L.A.-O.; Flenniken, M.A.-O. Longitudinal monitoring of honey bee colonies reveals dynamic nature of virus abundance and indicates a negative impact of Lake Sinai virus 2 on colony health. PLoS ONE 2020, 15, e0237544. [CrossRef] [PubMed]

92. Alger, S.A.; Burnham, P.A.; Lamas, Z.S.; Brody, A.K.; Richardson, L.L. Home sick: Impacts of migratory beekeeping on honey bee (Apis mellifera) pests, pathogens, and colony size. Peer] 2018, 6, e5812. [CrossRef]

93. Ricigliano, V.A.; Mott, B.M.; Floyd, A.S.; Copeland, D.C.; Carroll, M.J.; Anderson, K.E. Honey bees overwintering in a southern climate: Longitudinal effects of nutrition and queen age on colony-level molecular physiology and performance. Sci. Rep. 2018, 8, 10475. [CrossRef] [PubMed]

94. van Engelsdorp, D.; Tarpy, D.R.; Lengerich, E.J.; Pettis, J.S. Idiopathic brood disease syndrome and queen events as precursors of colony mortality in migratory beekeeping operations in the eastern United States. Prev. Vet. Med. 2013, 108, 225-233. [CrossRef] [PubMed]

95. Genersch, E.; von der Ohe, W.; Kaatz, H.; Schroeder, A.; Otten, C.; Büchler, R.; Berg, S.; Ritter, W.; Mühlen, W.; Gisder, S.; et al. The German bee monitoring project: A long term study to understand periodically high winter losses of honey bee colonies. Apidologie 2010, 41, 332-352. [CrossRef]

96. Nazzi, F.; Pennacchio, F. Disentangling multiple interactions in the hive ecosystem. Trends Parasitol. 2014, 30, 556-561. [CrossRef]

97. Deboutte, W.; Beller, L.; Yinda, C.K.; Shi, C.; Smets, L.; Vanmechelen, B.; Conceição-Neto, N.; Dallmeier, K.; Maes, P.; de Graaf, D.C.; et al. Hymenoptera associated eukaryotic virome lacks host specificity. bioRxiv 2020. [CrossRef]

98. Pisanty, G.; Mandelik, Y. Profiling crop pollinators: Life history traits predict habitat use and crop visitation by Mediterranean wild bees. Ecol. Appl. 2015, 25, 742-752. [CrossRef]

99. Pisanty, G.; Afik, O.; Wajnberg, E.; Mandelik, Y. Watermelon pollinators exhibit complementarity in both visitation rate and single-visit pollination efficiency. J. Appl. Ecol. 2016, 53, 360-370. [CrossRef]

100. Evans, J.D.; Schwarz, R.; Childers, A. HoloBee Database v2016.1. Ag Data Commons. 2016. Available online: https://doi.org/10 .15482/USDA.ADC/1255217 (accessed on 1 February 2019).

101. Bolger, A.M.; Lohse, M.; Usadel, B. Trimmomatic: A flexible trimmer for Illumina sequence data. Bioinformatics 2014, 30, 2114-2120. [CrossRef] [PubMed]

102. Kim, D.; Langmead, B.; Salzberg, S.L. HISAT: A fast spliced aligner with low memory requirements. Nat. Methods 2015, 12, 357-360. [CrossRef]

103. Li, H.; Handsaker, B.; Fau-Wysoker, A.; Wysoker, A.; Fau-Fennell, T.; Fennell, T.; Fau-Ruan, J.; Ruan, J.; Fau-Homer, N.; Homer, N.; et al. The Sequence Alignment/Map format and SAMtools. Bioinformatics 2009, 25, 2078-2079. [CrossRef] [PubMed]

104. Runckel, C.; DeRisi, J.; Flenniken, M.L. A draft genome of the honey bee trypanosomatid parasite Crithidia mellificae. PLoS ONE 2014, 9, e95057. [CrossRef] [PubMed]

105. Bray, N.L.; Pimentel, H.; Melsted, P.A.-O.; Pachter, L. Near-optimal probabilistic RNA-seq quantification. Nat. Biotechnol. 2016, 34, 525-527. [CrossRef] [PubMed]

106. Altschul, S.F.; Gish, W.; Miller, W.; Myers, E.W.; Lipman, D.J. Basic local alignment search tool. J. Mol. Biol. 1990, 215 , 403-410. [CrossRef]

107. Buchfink, B.; Xie, C.; Huson, D.H. Fast and sensitive protein alignment using DIAMOND. Nat. Methods 2015, 12, 59-60. [CrossRef]

108. de Miranda, J.R.; Bailey, L.; Ball, B.V.; Blanchard, P.; Budge, G.E.; Chejanovsky, N.; Chen, Y.-P.; Gauthier, L.; Genersch, E.; de Graaf, D.C.; et al. Standard methods for virus research in Apis mellifera. J. Apic. Res. 2015, 52, 1-56. [CrossRef]

109. Ginzinger, D.G. Gene quantification using real-time quantitative PCR: An emerging technology hits the mainstream. Exp. Hematol. 2002, 30, 503-512. [CrossRef]

110. R Core Team. R: A Language and Environment for Statistical Computing. R Foundation for Statistical Computing, Vienna, Austria. 2020. Available online: http:/ /www.R-project.org/ (accessed on 9 January 2020).

111. Daughenbaugh, K.F.; Martin, M.; Brutscher, L.M.; Cavigli, I.; Garcia, E.; Lavin, M.; Flenniken, M.L. Honey Bee Infecting Lake Sinai Viruses. Viruses 2015, 7, 3285-3309. [CrossRef] [PubMed]

112. Hunter, W.B. Medium for development of bee cell cultures (Apis mellifera: Hymenoptera: Apidae). In Vitro Cell. Dev. Biol. Anim. 2010, 46, 83-86. [CrossRef]

113. Altschul, S.F.; Madden, T.L.; Schäffer, A.A.; Zhang, J.; Zhang, Z.; Miller, W.; Lipman, D.J. Gapped BLAST and PSI-BLAST: A new generation of protein database search programs. Nucleic Acids Res. 1997, 25, 3389-3402. [CrossRef]

114. Eddy, S.R. Accelerated Profile HMM Searches. PLoS Comput. Biol. 2011, 7, e1002195. [CrossRef] [PubMed]

115. Greninger, A.L.; Makhsous, N.; Shean, R.; Jerome, K.; Crawford, R. Genome Sequences of Viruses from Spiders around Seattle. 2020. Available online: https://www.genome.jp/virushostdb/1911102 (accessed on 10 January 2020). 
116. Katoh, K.; Kuma, K.; Fau-Toh, H.; Toh, H.; Fau-Miyata, T.; Miyata, T. MAFFT version 5: Improvement in accuracy of multiple sequence alignment. Nucleic Acids Res. 2005, 33, 511-518. [CrossRef] [PubMed]

117. Capella-Gutiérrez, S.; Silla-Martínez, J.M.; Gabaldón, T. trimAl: A tool for automated alignment trimming in large-scale phylogenetic analyses. Bioinformatics 2009, 25, 1972-1973. [CrossRef]

118. Darriba, D.; Gl Fau-Doallo, R.T.; Doallo, R.; Fau-Posada, D.; Posada, D. ProtTest 3: Fast selection of best-fit models of protein evolution. Bioinformatics 2011, 27, 1164-1165. [CrossRef]

119. Guindon, S.; Dufayard, J.-F.; Lefort, V.; Anisimova, M.; Hordijk, W.; Gascuel, O. New Algorithms and Methods to Estimate Maximum-Likelihood Phylogenies: Assessing the Performance of PhyML 3.0. Syst. Biol. 2010, 59, 307-321. [CrossRef]

120. Rambaut, A.D.A. FigTree Version 1.4.0. Available online: http://tree.bio.ed.ac.uk/software/figtree/ (accessed on 9 January 2020).

121. Bates, D.; Maechler, M.; Bolker, B.; Walker, S. Package 'lme4'. Available online: http://dk.archive.ubuntu.com/pub/pub/cran/ web/packages/lme4/lme4.pdf (accessed on 9 January 2020).

122. Ben Bolker, R.D.C.T. bbmle: Tools for General Maximum Likelihood Estimation Methods and Functions for Fitting Maximum Likelihood Models in R. Available online: https:/ /CRAN.R-project.org/package=bbmle (accessed on 9 January 2020).

123. Hartig, F. DHARMa: Residual Diagnostics for Hierarchical (Multi-Level/Mixed) Regression Models. Available online: https: / / cran.r-project.org/web/packages/DHARMa/vignettes/DHARMa.html (accessed on 9 January 2020).

124. Fortin, M.-J.; Dale, M.R.T. Spatial Analysis: A Guide for Ecologists; Cambridge University Press: Cambridge, UK, 2005.

125. Consortium, H.G.S. Insights into social insects from the genome of the honeybee Apis mellifera. Nature 2006, 443, 931-949.

126. Elsik, C.G.; Worley, K.C.; Bennett, A.K.; Beye, M.; Camara, F.; Childers, C.P.; de Graaf, D.C.; Debyser, G.; Deng, J.; Devreese, B.; et al. Finding the missing honey bee genes: Lessons learned from a genome upgrade. BMC Genom. 2014, 15, 86. [CrossRef]

127. Moore, J.; Jironkin, A.; Chandler, D.; Burroughs, N.; Evans, D.J.; Ryabov, E.V. Recombinants between Deformed wing virus and Varroa destructor virus-1 may prevail in Varroa destructor-infested honeybee colonies. J. Gen. Virol. 2010, 92, 156-161. [CrossRef] [PubMed]

128. Chen, Y.P.; Pettis, J.S.; Zhao, Y.; Liu, X.; Tallon, L.J.; Sadzewicz, L.D.; Li, R.; Zheng, H.; Huang, S.; Zhang, X.; et al. Genome sequencing and comparative genomics of honey bee microsporidia, Nosema apis reveal novel insights into host-parasite interactions. BMC Genom. 2013, 14, 451. [CrossRef] [PubMed]

129. Cornman, R.S.; Chen, Y.P.; Schatz, M.C.; Street, C.; Zhao, Y.; Desany, B.; Egholm, M.; Hutchison, S.; Pettis, J.S.; Lipkin, W.I.; et al. Genomic Analyses of the Microsporidian Nosema ceranae, an Emergent Pathogen of Honey Bees. PLoS Pathog. 2009, 5, e1000466. [CrossRef]

130. Cornman, S.R.; Schatz, M.C.; Johnston, S.J.; Chen, Y.P.; Pettis, J.; Hunt, G.; Bourgeois, L.; Elsik, C.; Anderson, D.; Grozinger, C.M.; et al. Genomic survey of the ectoparasitic mite Varroa destructor, a major pest of the honey bee Apis mellifera. BMC Genom. 2010, 11, 602. [CrossRef] [PubMed]

131. Bigot, D.; Dalmon, A.; Roy, B.; Hou, C.; Germain, M.; Romary, M.; Deng, S.; Diao, Q.; Weinert, L.A.; Cook, J.M.; et al. The discovery of Halictivirus resolves the Sinaivirus phylogeny. J. Gen. Virol. 2017, 98, 2864-2875. [CrossRef] [PubMed]

132. Cornman, R.A.-O. Relative Abundance and Molecular Evolution of Lake Sinai Virus (Sinaivirus) Clades. PeerJ 2019,7 , e6305. [CrossRef] [PubMed]

133. Iwanowicz, D.D.; Wu-Smart, J.Y.; Olgun, T.; Smart, A.H.; Otto, C.R.V.; Lopez, D.; Evans, J.D.; Cornman, R. An updated genetic marker for detection of Lake Sinai Virus and metagenetic applications. Peer] 2020, 8, e9424. [CrossRef]

134. Haas, B.J.; Papanicolaou, A.; Yassour, M.; Grabherr, M.; Blood, P.D.; Bowden, J.; Couger, M.B.; Eccles, D.; Li, B.; Lieber, M.; et al. De novo transcript sequence reconstruction from RNA-seq using the Trinity platform for reference generation and analysis. Nat. Protoc. 2013, 8, 1494-1512. [CrossRef]

135. Moustafa, I.M.; Korboukh, V.K.; Arnold, J.J.; Smidansky, E.D.; Marcotte, L.L.; Gohara, D.W.; Yang, X.; Sánchez-Farrán, M.A.; Filman, D.; Maranas, J.K.; et al. Structural dynamics as a contributor to error-prone replication by an RNA-dependent RNA polymerase. J. Biol. Chem. 2014, 289, 36229-36248. [CrossRef]

136. Lauring, A.S. Within-Host Viral Diversity: A Window into Viral Evolution. Annu. Rev. Virol. 2020, 7, 63-81. [CrossRef] [PubMed]

137. Lauring, A.S.; Andino, R. Quasispecies Theory and the Behavior of RNA Viruses. PLoS Pathog. 2010, 6, e1001005. [CrossRef]

138. Andino, R.; Domingo, E. Viral quasispecies. Virology 2015, 479-480, 46-51. [CrossRef]

139. Thaduri, S.; Locke, B.; Granberg, F.; de Miranda, J.R. Temporal changes in the viromes of Swedish Varroa-resistant and Varroasusceptible honeybee populations. PLoS ONE 2018, 13, e0206938. [CrossRef]

140. Yue, C. RT-PCR analysis of Deformed wing virus in honeybees (Apis mellifera) and mites (Varroa destructor). J. Gen. Virol. 2005, 86, 3419-3424. [CrossRef] [PubMed]

141. McNeil, D.J.; McCormick, E.; Heimann, A.C.; Kammerer, M.; Douglas, M.R.; Goslee, S.C.; Grozinger, C.M.; Hines, H.M. Bumble bees in landscapes with abundant floral resources have lower pathogen loads. Sci. Rep. 2020, 10, 22306. [CrossRef]

142. Annoscia, D.; Brown, S.P.; Di Prisco, G.; De Paoli, E.; Del Fabbro, S.; Frizzera, D.; Zanni, V.; Galbraith, D.A.; Caprio, E.; Grozinger, C.M.; et al. Haemolymph removal by Varroa mite destabilizes the dynamical interaction between immune effectors and virus in bees, as predicted by Volterra's model. Proc. Biol. Sci. 2019, 286, 20190331. [CrossRef] [PubMed]

143. Zhao, Y.; Heerman, M.; Peng, W.; Evans, J.D.; Rose, R.; De Grandi-Hoffman, G.; Simone-Finstrom, M.; Li, J.; Li, Z.; Cook, S.C.; et al. The Dynamics of Deformed Wing Virus Concentration and Host Defensive Gene Expression after Varroa Mite Parasitism in Honey Bees, Apis mellifera. Insects 2019, 10, 16. [CrossRef] [PubMed] 
144. Zioni, N.; Soroker, V.; Chejanovsky, N. Replication of Varroa destructor virus 1 (VDV-1) and a Varroa destructor virus 1-deformed wing virus recombinant (VDV-1-DWV) in the head of the honey bee. Virology 2011, 417, 106-112. [CrossRef]

145. Barroso-Arévalo, S.; Fernández-Carrión, E.; Goyache, J.; Molero, F.; Puerta, F.; Sánchez-Vizcaíno, J.M. High Load of Deformed Wing Virus and Varroa destructor Infestation Are Related to Weakness of Honey Bee Colonies in Southern Spain. Front. Microbiol. 2019, 10, 1331. [CrossRef] [PubMed]

146. de Miranda, J.R.; Genersch, E. Deformed wing virus. J. Invertebr. Pathol. 2010, 103, S48-S61. [CrossRef]

147. Genersch, E. Honey bee pathology: Current threats to honey bees and beekeeping. Appl. Microbiol. Biotechnol. 2010, 87, 87-97. [CrossRef] [PubMed]

148. McMenamin, A.J.; Genersch, E. Honey bee colony losses and associated viruses. Curr. Opin. Insect Sci. 2015, 8, 121-129. [CrossRef]

149. Kevill, J.L.; Highfield, A.; Mordecai, G.J.; Martin, S.J.; Schroeder, D.C. ABC Assay: Method Development and Application to Quantify the Role of Three DWV Master Variants in Overwinter Colony Losses of European Honey Bees. Viruses 2017, 9, 314. [CrossRef]

150. Dalmon, A.; Desbiez, C.; Coulon, M.; Thomasson, M.; Le Conte, Y.; Alaux, C.; Vallon, J.; Moury, B. Evidence for positive selection and recombination hotspots in Deformed wing virus (DWV). Sci. Rep. 2017, 7, 41045. [CrossRef] [PubMed]

151. Dubois, E.; Dardouri, M.; Schurr, F.; Cougoule, N.; Sircoulomb, F.; Thiéry, R. Outcomes of honeybee pupae inoculated with deformed wing virus genotypes A and B. Apidologie 2020, 51, 18-34. [CrossRef]

152. Mockel, N.; Gisder, S.; Genersch, E. Horizontal transmission of deformed wing virus: Pathological consequences in adult bees (Apis mellifera) depend on the transmission route. J. Gen. Virol. 2011, 92, 370-377. [CrossRef]

153. Ravoet, J.; De Smet, L.; Wenseleers, T.; de Graaf, D.C. Genome sequence heterogeneity of Lake Sinai Virus found in honey bees and Orf1/RdRP-based polymorphisms in a single host. Virus Res. 2015, 201, 67-72. [CrossRef]

154. Chevin, A.; Coutard, B.; Blanchard, P.; Dabert-Gay, A.-S.; Ribière-Chabert, M.; Thiéry, R. Characterisation of Structural Proteins from Chronic Bee Paralysis Virus (CBPV) Using Mass Spectrometry. Viruses 2015, 7, 3329-3344. [CrossRef]

155. Zimmermann, L.; Stephens, A.; Nam, S.-Z.; Rau, D.; Kübler, J.; Lozajic, M.; Gabler, F.; Söding, J.; Lupas, A.N.; Alva, V. A Completely Reimplemented MPI Bioinformatics Toolkit with a New HHpred Server at its Core. J. Mol. Biol. 2018, 430, 2237-2243. [CrossRef] [PubMed]

156. Pascall, D.J.; Tinsley, M.C.; Obbard, D.J.; Wilfert, L. Host evolutionary history predicts virus prevalence across bumblebee species. bioRxiv 2019. [CrossRef]

157. Carrillo-Tripp, J.; Dolezal, A.G.; Goblirsch, M.J.; Miller, W.A.; Toth, A.L.; Bonning, B.C. In vivo and in vitro infection dynamics of honey bee viruses. Sci. Rep 2016, 6, S50. [CrossRef]

158. Guo, Y.; Goodman, C.L.; Stanley, D.W.; Bonning, B.C. Cell Lines for Honey Bee Virus Research. Viruses 2020, 12, 236. [CrossRef]

159. Goblirsch, M.J.; Spivak, M.S.; Kurtti, T.J. A Cell Line Resource Derived from Honey Bee (Apis mellifera) Embryonic Tissues. PLoS ONE 2013, 8, e69831. [CrossRef]

160. McMahon, D.P.; Fürst, M.A.; Caspar, J.; Theodorou, P.; Brown, M.J.F.; Paxton, R.J. A sting in the spit: Widespread cross-infection of multiple RNA viruses across wild and managed bees. J. Anim. Ecol. 2015, 84, 615-624. [CrossRef]

161. Graystock, P.; Ng, W.H.; Parks, K.; Tripodi, A.D.; Muñiz, P.A.; Fersch, A.A.; Myers, C.R.; McFrederick, Q.S.; McArt, S.H. Dominant bee species and floral abundance drive parasite temporal dynamics in plant-pollinator communities. Nat. Ecol. Evol. 2020, 4, 1358-1367. [CrossRef] [PubMed]

162. Ostfeld, R.S.; Keesing, F. Biodiversity and Disease Risk: The Case of Lyme Disease. Conserv. Biol. 2000, 14, 722-728. [CrossRef]

163. Figueroa, L.L.; Grab, H.; Ng, W.H.; Myers, C.R.; Graystock, P.; McFrederick, Q.S.; McArt, S.H. Landscape simplification shapes pathogen prevalence in plant-pollinator networks. Ecol. Lett. 2020, 23, 1212-1222. [CrossRef]

164. Luis, A.D.; Kuenzi, A.J.; Mills, J.N. Species diversity concurrently dilutes and amplifies transmission in a zoonotic host-pathogen system through competing mechanisms. Proc. Natl. Acad. Sci. USA 2018, 115, 7979-7984. [CrossRef]

165. De Grandi-Hoffman, G.; Chen, Y. Nutrition, immunity and viral infections in honey bees. Curr. Opin. Insect Sci. 2015, 10, 170-176. [CrossRef]

166. Alaux, C.; Dantec, C.; Parrinello, H.; Le Conte, Y. Nutrigenomics in honey bees: Digital gene expression analysis of pollen's nutritive effects on healthy and varroa-parasitized bees. BMC Genom. 2011, 12, 583. [CrossRef] [PubMed]

167. Dolezal, A.G.; Toth, A.L. Feedbacks between nutrition and disease in honey bee health. Curr. Opin. Insect Sci. 2018, 26, 114-119. [CrossRef] [PubMed]

168. Wenner, A.M.; Meade, D.E.; Friesen, L.J. Recruitment, Search Behavior, and Flight Ranges of Honey Bees1. Am. Zool 1991, 31, 768-782. [CrossRef] 